\title{
Upgraded valorization of copper (II) immobilization onto Schiff base-functionalized pectin grafted magnetic nanoparticles: A thermostable, reusable, and efficient nanocatalyst for the green synthesis of 1,2,3-triazole in pure water
}

Hossein Khashei Siuki

University of birjand

\section{Pouya Ghamari Kargar}

University of birjand https://orcid.org/0000-0002-6284-2874

Ghodsieh Bagherzade ( $\sim$ bagherzadeh@birjand.ac.ir)

University of birjand https://orcid.org/0000-0003-2931-8146

Research Article

Keywords: Click reaction, Heterogeneous catalyst, Magnetic nanoparticles, Pectin, Polymer, Triazole

Posted Date: August 3rd, 2021

DOI: https://doi.org/10.21203/rs.3.rs-775331/v1

License: (1) (i) This work is licensed under a Creative Commons Attribution 4.0 International License.

Read Full License 


\title{
Upgraded valorization of copper (II) immobilization onto Schiff base- functionalized pectin grafted magnetic nanoparticles: A thermostable, reusable, and efficient nanocatalyst for the green synthesis of 1,2,3-triazole in pure water
}

\author{
Hossein Khashei Siuki, Pouya Ghamari Kargar, \& Ghodsieh Bagherzade*
}

* Corresponding authors: E-mail: P.Ghamari71@gmail.com, gbagherzade@gmail.com; bagherzadeh@birjand.ac.ir. Fax: +98 56 32345192; Tel: +9856 32345192

${ }^{a}$ Department of Chemistry, Faculty of Sciences, University of Birjand, Birjand, 97175-615, Iran.

\begin{abstract}
In this project, the new catalyst copper defines as $\mathrm{Fe}_{3} \mathrm{O}_{4} @ P e c t i n @\left(\mathrm{CH}_{2}\right)_{3}$-Acetamide- $\mathrm{Cu}$ (II) was successfully manufactured and fully characterized by different techniques, including FT-IR, XRD, TEM, FESEM, EDX, VSM, and ICP analysis. All results showed that copper was successfully supported on the polymer-coated magnetic nanoparticles. One of the most important properties of a catalyst is the ability to be prepared from simple materials such as pectin that's a biopolymer that is widely found in nature. The catalytic activity of $\mathrm{Fe}_{3} \mathrm{O}_{4} @ P e c t i n @\left(\mathrm{CH}_{2}\right)_{3}$ Acetamide-Cu(II) was examined in a classical, one pot, and the three-component reaction of terminal alkynes, alkyl halides, and sodium azide in water and observed, proceeding smoothly and completed in good yields and high regioselectivity. The critical potential interests of the present method include high yields, recyclability of catalyst, easy workup, using an eco-friendly solvent, and the ability to sustain a variety of functional groups, which give economical as well as ecological rewards. The capability of the nanocomposite was compared with previous works, and the nanocomposite was found more efficient, economical, and reproducible. Also, the catalyst can be easily removed from the reaction solution using an external magnet and reused for five runs without reduction in catalyst activity
\end{abstract}

Keywords: Click reaction, Heterogeneous catalyst, Magnetic nanoparticles, Pectin, Polymer, Triazole

\section{Introduction}

Over the last decade, much interest has been shown in the synthesis of 1,2,3-triazole unit. 1,2,3-Triazoles are important and useful heterocycles. Apart from pharmaceutical applications, where these units are important for their biological activity or as an amide bond isostere, they are also important in material science and chemical biology [1, 2]. Also, other uses include: as chemical agents, dyes, corrosion inhibitors, photo stabilizers and photographic materials. Several 1,2,3-triazole derivatives show interesting biological activities. [3-7] One of the most general methods for the syntheses of 1,2,3-triazole derivatives is the classical Huisgen [8] cycloaddition reaction that involves the thermal 1, 3-dipolar cycloaddition of organic azides with alkynes. However, it is in low efficiency and mixed regioselectivity. Research groups of Sharpless [9] and Meldal's [10], later independently developed the Huisgen 1, 3-dipolar cycloaddition reaction method with a copper (I) catalyzed, which the "click" reaction is widely studied. Also, according to several recent studies in the literature since 2010, the catalyzed reaction of click with copper has been widely reflected in various branches of science. [11] To make the CuAAC reactions functional, many efforts have been made, concentrating on discovering new and more significant synthetic strategies [12-14]. In CuAAC reactions, copper has an outstanding role in the synthesis of 1,2,3-triazole derivatives. On the basis of the work of Sharpless and Medal, different copper sources such as Cu (I) [15-20], MNP@PIL-Cu [21], Cu-complex [22], Cu NPs [23], and HMS-DP-Cu(II) [24] have been tested. Moreover, in recent years, in order to synthesize triazoles, many other methods have been suggested [25-27]. Although these simple procedures are feasible for many reactions, they have a major drawback; when copper salts are used as a homogeneous catalyst, it faces problems such as difficult separation and recycling of the catalyst, cytotoxicity, and environmental pollution. Since removing trace amounts of metal contaminants from the products is necessary, particularly in the pharmaceutical industry, copper catalysts should be fully separated from the products. Thus, the heterogeneously catalyzed procedures are advantageous for such 
reactions. During the past few years, copper ions have been immobilized onto a large variety of solid supports, including agarose [28], polymers [29], chitosan [30], silica [31], cellulose [32], eggshell [33], and graphene [34] that assist in controlling reactivity and selectivity besides the advantage of easy workability. However, it is complicated to remove a homogeneous copper catalyst from the reaction medium after the reaction has been completed. While removing a small amount of metal contamination from products, especially pharmaceuticals, is essential, copper catalysts should be completely removed from the product [35-38]. To solve this problem, heterogeneous copper catalysts should be used instead of homogeneous copper catalysts. The choice of materials that have been used for immobilization of copper complexes is essential, which can be referred to as magnetic nanoparticles. Magnetic nanoparticles are a group of advanced nanomaterials with specific applications, properties and sizes and are very efficient in the synthesis of heterogeneous catalysts. Among the properties of magnetic nanoparticles are biological, biomedical, environmental, low toxicity and cost-effectiveness. [39] The magnetic nanoparticles have been the focus of much research recently because they possess attractive properties which could see potential use in catalysis, including nanomaterial-based catalysts,[40] biomedicine [41] and tissue-specific targeting,[42] magnetically tunable colloidal photonic crystals,[43] microfluidics,[44] magnetic resonance imaging,[45] magnetic particle imaging,[46] data storage,[47][48] environmental remediation,[49] nanofluids,[50,51] optical filters,[52] defect sensor,[53] magnetic cooling[54][55] and cation sensors.[56] One of the significant problems of magnetic nanoparticles is their nakedness problem, which is due to the small distance between the particles and to some extent the high surface energy and the presence of van der Waals forces. The above points cause the nanoparticles to be subjected to the accumulation of the reaction mixture. [57]. The accumulation of particles affects their properties. The effect is accompanied by catalytic reactions. To maintain these properties, magnetic nanoparticles are continuously modified by placing stabilizing coatings in active sites to prevent their irreversible accumulation. Iron oxide-like outer shells such as polymers [58], zeolites [59], titanium dioxide [60], silica [61] and carbon [62] being investigated. The choice of supporting materials for the catalyst is essential because it determines the activity, thermal durability, and reproducibility of the catalyst in catalytic reactions. [63] Hence, magnetic nanocomposites are very important as a substrate for catalysts due to their wide surface area, easy preparation and green nature. [64] Pectin is a natural polysaccharide copolymer that is present in the walls of primary cells and is extracted from fruits and vegetables. [65] The structure of pectin depends on its source and extraction process. Pectin has properties such as biodegradable, biocompatible, bioactive, and is used in food, cosmetics, medicine, and biology. [66]

In this study, a highly efficient and recyclable copper catalyst first designed from pectin, a low-cost, harmless, and green biopolymer for organic reactions. In summary, amino-functionalized pectin (Pectin- $\mathrm{NH}_{2}$ ) was obtained by mixing pectin with (3-Aminopropyl) trimethoxy silane (APTMS) in toluene. Schiff base reaction was performed with the reaction of $\mathrm{NH}_{2}$-grafted pectin with acetamide. Finally, the copper catalyst was easily prepared by stirring of Schiff base functionalized pectin $\left(\mathrm{Fe}_{3} \mathrm{O}_{4} @\right.$ Pectin@ $\left(\mathrm{CH}_{2}\right)_{3}$-Acetamide) and copper acetate in ethanol (Scheme 1). This novel catalyst was fully analyzed by several instrumental techniques and applied as a water-dispersible/magnetically reusable copper (II) catalyst for the 1,2,3-triazole click reactions in aqueous media. The designed copper catalyst showed highly efficient catalytic activity for click reactions of aryl halides, Sodium azide, and alkynes; in addition, the copper catalyst showed superior reusability by producing high-efficiency products even after five cycles. 


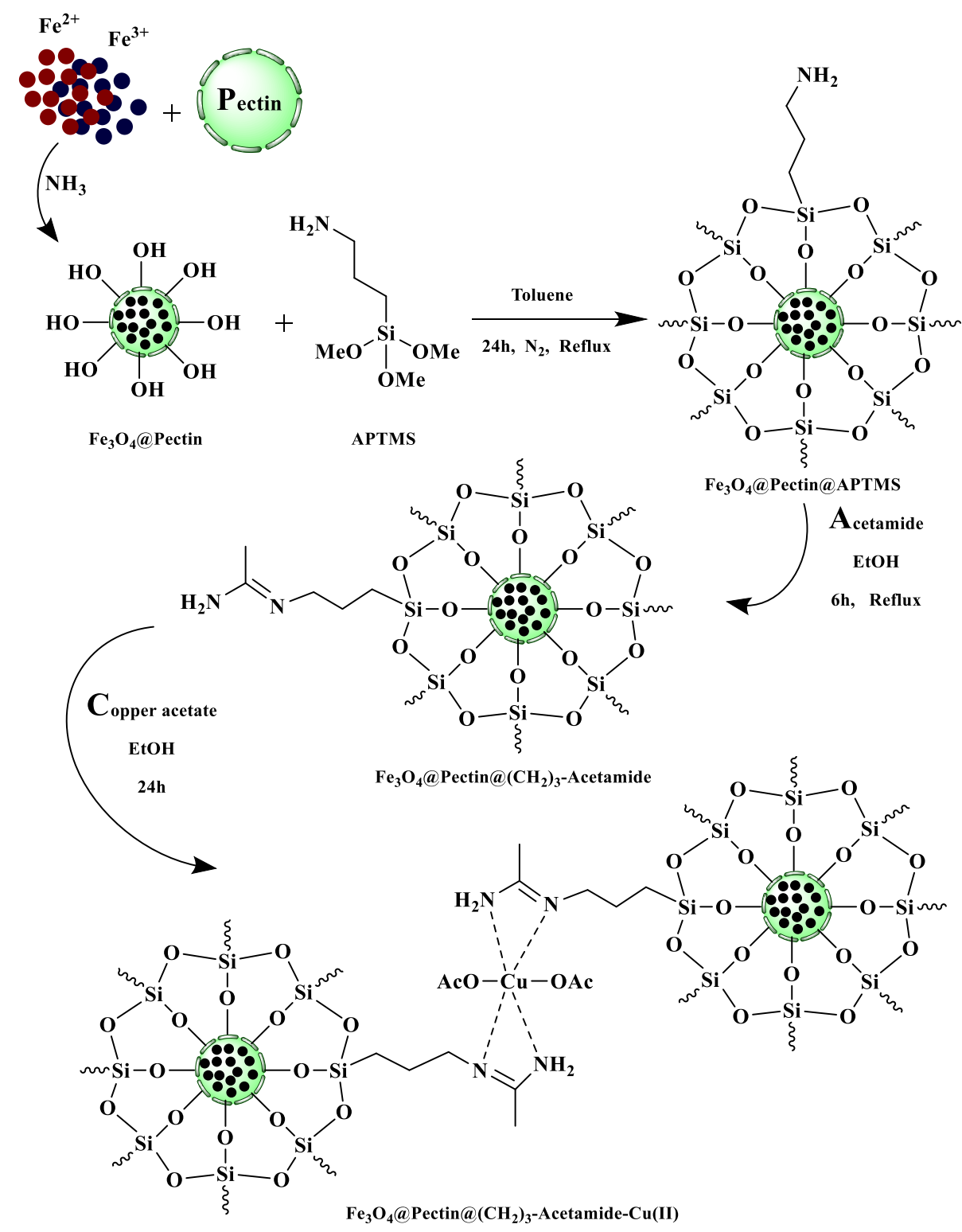

Scheme 1: The general synthetic approach for preparation of the $\mathrm{Fe}_{3} \mathrm{O}_{4} @ P e c t i n @\left(\mathrm{CH}_{2}\right)_{3}-\mathrm{Acetamide}-\mathrm{Cu}(\mathrm{II})$

\section{Experimental}

\section{Materials and physicochemical characterization}

Ferric chloride hexahydrate $\left(\mathrm{FeCl}_{3} \cdot 6 \mathrm{H}_{2} \mathrm{O},>99 \%\right)$ and ferrous chloride tetrahydrate $\left(\mathrm{FeCl}_{2} \cdot 4 \mathrm{H}_{2} \mathrm{O}\right)$ were used as an iron source. Pectin with the degree of esterification of $76 \%$ and other materials used in this article were from Merck (Germany) and Sigma Aldrich and were used without further purification. The reaction progress and purity of the products were determined using TLC on silica-gel Polygram SILG/UV254 plates. FT-IR spectra were recorded with a Nicolet system 800 beam splitter KBr SCAL $=800$ in the $400-4000 \mathrm{~cm}^{-1}$. Transmission electron microscope (TEM) investigations were performed using a Philips EM 208S Transmission Electron Microscope. Thermogravimetric analysis (TGA) was also recorded under argon and air atmosphere using TGA/TDA Q600 TA Instruments. Melting 
points were determined using an electrothermal 9100 device. The powder X-ray diffraction (XRD) was performed within Philips PW1730 with a $\mathrm{Cu} \mathrm{K} \alpha(\lambda=1.54060 \AA)$ radiation. SEM-EDX was recorded by Fe-SEM TESCAN MIRA3. The ${ }^{1} \mathrm{H}$ NMR $(250 \mathrm{MHz})$ and ${ }^{13} \mathrm{CNMR}(62.9 \mathrm{MHz})$ analyses were performed on a Bruker Avance DPX-250 spectrometer in $\mathrm{CDCl}_{3}$ and DMSO- $\mathrm{d}_{6}$ as solvent and TMS as internal standard.

\subsection{Synthesis of $\mathrm{Fe}_{3} \mathrm{O}_{4} @$ Pectin}

Core-shell $\mathrm{Fe}_{3} \mathrm{O}_{4} @$ Pectin nanospheres were prepared in terms of the previously described method.[67] According to this, $0.5 \mathrm{~g}$ of pectin dissolves in $50 \mathrm{ml}$ of distilled water under stirring until a homogeneous dispersion of pectin is obtained. $\mathrm{FeCl}_{3} \cdot 6 \mathrm{H}_{2} \mathrm{O}(3 \mathrm{~g})$ and $\mathrm{FeCl}_{2} \cdot 4 \mathrm{H}_{2} \mathrm{O}(1.6 \mathrm{~g})$ dissolve in $25 \mathrm{ml}$ of distilled water separately and then add them. Then slowly added them to the mixture containing pectin, which resulted in a brown gel. The reaction mixture was stirred under a gentle flow of $\mathrm{N}_{2}$ at $85^{\circ} \mathrm{C}$ for $2 \mathrm{~h}$. After which an excess of ammonium hydroxide ( $\left.25 \mathrm{wt} \%\right)$ to the reaction mixture was added until the $\mathrm{pH}$ reaches 11-12 and the mixture becomes black indicating the formation of magnetite and again the mixture was under a gentle flow of $\mathrm{N}_{2}$ at $85^{\circ} \mathrm{C}$ for $30 \mathrm{~min}$. At the end the precipitate was removed from the reaction vessel and to reduce the $\mathrm{pH}$ washed with distilled water until $\mathrm{pH}$ reached the range of 7 , then precipitate dried under vacuum.

\subsection{Synthesis of $\mathrm{Fe}_{3} \mathrm{O}_{4} @$ Pectin@APTMS}

In the first step, synthesized $\mathrm{Fe}_{3} \mathrm{O}_{4} @$ Pectin $(1.7 \mathrm{~g})$ was sonicated in dry toluene $(30 \mathrm{ml})$ for $30 \mathrm{~min}$, and then 3-aminopropyl trimethoxy silane (APTMS: $1.1 \mathrm{ml}$ ) was added slowly to the mixture. Then the mixture was stirred for $1 \mathrm{~h}$ at room temperature. After stirring, the product obtained from $\mathrm{Fe}_{3} \mathrm{O}_{4} @$ Pectin and APTMS was exposed for $24 \mathrm{~h}$ under $\mathrm{N}_{2}$ gas at reflux conditions. After finishing the reaction, the solid obtained is separated by an exterior magnet and washed three times with $15 \mathrm{ml}$ of toluene. At the end, solid dried at $70{ }^{\circ} \mathrm{C}$ in oven under vacuum for $4 \mathrm{~h}$.

\subsection{Synthesis of $\mathrm{Fe}_{3} \mathrm{O}_{4} @$ Pectin@ $\left(\mathrm{CH}_{2}\right)_{3}$-Acetamide}

In the beginning, Acetamide $(2.12 \mathrm{mmol}, 0.129 \mathrm{~g})$ was dissolved in dry ethanol $(5 \mathrm{ml})$ and then slowly added to a 100 $\mathrm{ml}$ flask containing $45 \mathrm{ml}$ of ethanol and $\mathrm{Fe}_{3} \mathrm{O}_{4} @$ Pectin@APTMS $(1.97 \mathrm{~g}$ ), which were dispersed using ultrasound for $30 \mathrm{~min}$. The reaction mixture was refluxed for $6 \mathrm{~h}$. After, the mixture was cooled to room temperature. The resulting Schiff base immobilized on $\mathrm{Fe}_{3} \mathrm{O}_{4} @$ Pectin was separated by an external magnet, washed three times with ethanol and dried under vacuum.

\subsection{Synthesis of $\mathrm{Fe}_{3} \mathrm{O}_{4} @$ Pectin@ $\left(\mathrm{CH}_{2}\right)_{3}$-Acetamide- $\mathrm{Cu}$ (II)}

The synthesized $\mathrm{Fe}_{3} \mathrm{O}_{4} @$ Pectin@ $\left(\mathrm{CH}_{2}\right)_{3}$-Acetamide (1 $\mathrm{g}$ ) was dissolved in dry ethanol (5 ml) under sonication. Copper acetate was also dissolved separately in ethanol $(15 \mathrm{ml})$. The metal solution was slowly added to the solution containing the substrate under sonicate conditions. Then the reaction mixture is subjected to vigorous stirring for $24 \mathrm{~h}$ to place the copper metal on substrate $\mathrm{Fe}_{3} \mathrm{O}_{4} @ P e c t i n @\left(\mathrm{CH}_{2}\right)_{3}$-Acetamide. Finally, it separated the solid product from the solution and washed it with ethanol several times to remove excess copper from the catalyst, and it dried under vacuum (Scheme 1).

\subsection{The method of synthesizing triazole derivatives}

To a test tube on a magnetic stirrer containing catalyst $(0.5 \mathrm{~mol} \%)$ and $\mathrm{H}_{2} \mathrm{O}(2 \mathrm{ml})$ as a green solvent, Alkyl halides $(1.0 \mathrm{mmol})$, Sodium azide $(1.2 \mathrm{mmol})$, alkyne $(1.0 \mathrm{mmol})$ added. The reaction mixture was stirred at $65^{\circ} \mathrm{C}$ and the progress of the reaction was monitored by thin-layer chromatography (TLC). After the reaction is complete and the reaction mixture has cooled, the catalyst is removed from the reaction medium by an external magnet. A pure product was obtained by recrystallization from EtOAC-Water. The products were identified by comparing their melting points with those previously reported because the products are known compounds. The spectral data for the selected compounds are as follows: 


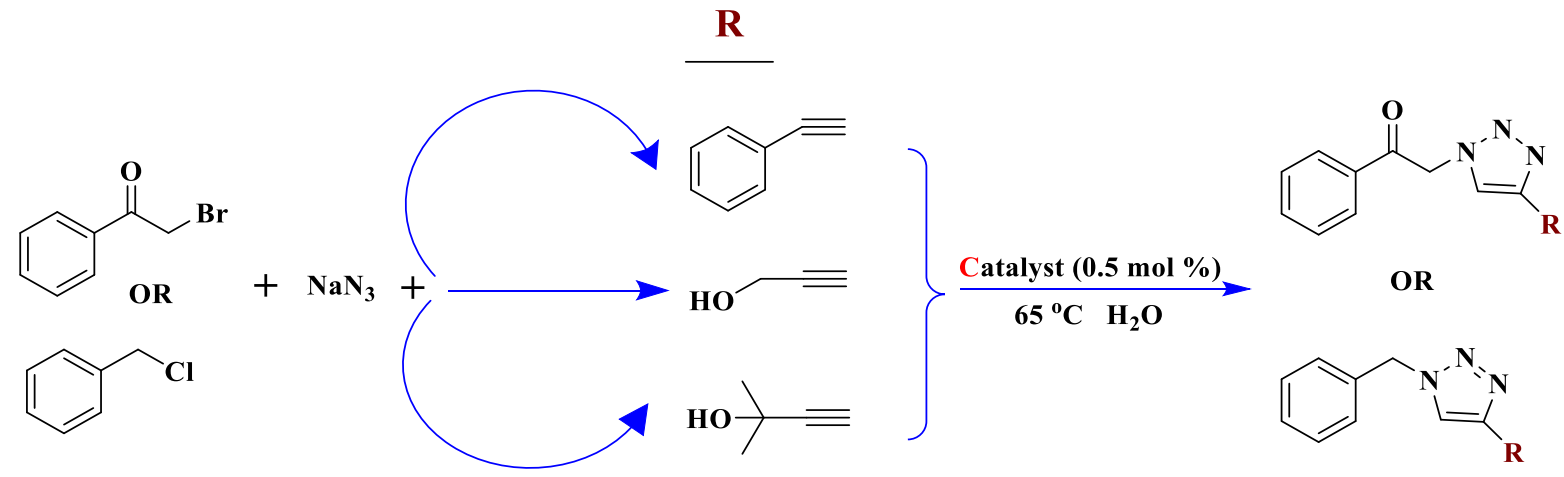

Scheme 2: Reaction of synthesis triazole derivatives in the presence of catalyst $\mathrm{Fe}_{3} \mathrm{O}_{4} @ \mathrm{Pectin} @\left(\mathrm{CH}_{2}\right)_{3}-\mathrm{Acetamide}-\mathrm{Cu}(\mathrm{II})$

1-benzyl-4-phenyl-1H-1,2,3-triazole (4a):

${ }^{1} \mathrm{HNMR}$ (DMSO, $300 \mathrm{MHz}$ ): $\delta=5.66$ (s, 2H, $\mathrm{CH}_{2}$ ), 7.34-7.45(m, 8H, H-Ar), 7.48 (s, 1H, CH of triazole), 7.85-7.87 (d, 2H, H-Ar) ppm.

${ }^{13} \mathrm{CNMR}$ (DMSO, $\left.75 \mathrm{MHz}\right): \delta=53.51,122.03,125.65,128.37,129.59,133.22,147.14 \mathrm{ppm}$.

Anal. calcd for $\mathrm{C}_{13} \mathrm{H}_{15} \mathrm{~N}_{3}$ : C, 75.57; H, 5.57; N, 17.86; found: C, 75.52; H, 5.58; N, 18.9. Mp ( $\left.{ }^{\circ} \mathrm{C}\right)$ : 127-129. [71]

1-(4-methylbenzyl)-4-phenyl-1H-1,2,3-triazole (4b):

${ }^{1} \mathrm{HNMR}$ (DMSO, $300 \mathrm{MHz}$ ): $\delta=2.308$ (s, 3H, $\mathrm{CH}_{3}$ ), 5.607 (s, 2H, $\mathrm{CH}_{2}$ ), 7.25(q, 3H, H-Ar), 7.36 (t, 2H, H-Ar), 7.45 (t, 2H, h-Ar), 7.69 (s, 1H, CH of triazole), 7.86 (d, 2H, H-Ar) ppm.

${ }^{13} \mathrm{CNMR}$ (DMSO, $75 \mathrm{MHz}$ ): $\delta=21.18,53.30,128.42,129.36,129.80,131.16,133.48,137.98,147.09$ ppm.

Anal. calcd for $\mathrm{C}_{16} \mathrm{H}_{15} \mathrm{~N}_{3}$ : C, 77.08; H, 6.06; N, 16.85; found: C, 77.11; H, 6.04; N, 16.85. M.p ( $\left.{ }^{\circ} \mathrm{C}\right)$ : 103-105. [72]

1-(4-chlorobenzyl)-4-phenyl-1H-1,2,3-triazole (4c):

${ }^{1} \mathrm{HNMR}$ (DMSO, $300 \mathrm{MHz}$ ): $\delta=5.76$ (s, 2H, $\mathrm{CH}_{2}$ ), 7.24 (d, 2H, H-Ar), 7.34 (d, 2H, H-Ar), 7.62 (q, 3H, H-Ar), 7.77 (s, 1H, CH of triazole), 7.86 (d, 2H, H-Ar) ppm.

Anal. calcd for $\mathrm{C}_{15} \mathrm{H}_{12} \mathrm{ClN}_{3}$ : C, 66.79; H, 4.48; $\mathrm{Cl}, 13.14 ; \mathrm{N}, 15.58$; found: $\mathrm{C}, 66.59 ; \mathrm{H}, 4.72 ; \mathrm{N}, 15.54$. M.p $\left({ }^{\circ} \mathrm{C}\right)$ : $145-147$ [73]

\section{1-(2-chlorobenzyl)-4-phenyl-1H-1,2,3-triazole (4d):}

${ }^{1} \mathrm{HNMR}$ (DMSO, $300 \mathrm{MHz}$ ): $\delta=5.77$ (s, 2H, $\mathrm{CH}_{2}$ ), 7.34 (3H, H-Ar), 7.45 (3H, H-Ar), 7.57 (d, 1H, H-Ar), 7.67 (s, $1 \mathrm{H}, \mathrm{CH}$ of triazole), 7.86 (d, 2H, H-Ar) ppm.

${ }^{13} \mathrm{CNMR}$ (DMSO, $75 \mathrm{MHz}$ ): $\delta=51.27,125.68,127.24,128.28,129.38,130.76,130.99,133.66,138.79,146.94 \mathrm{ppm}$. Anal. calcd for $\mathrm{C}_{15} \mathrm{H}_{12} \mathrm{ClN}_{3}$ : C, 66.79; $\mathrm{H}, 4.48 ; \mathrm{Cl}, 13.14 ; \mathrm{N}, 15.58$; found: $\mathrm{C}, 66.61 ; \mathrm{H}, 4.53 ; \mathrm{N}, 15.561 . \mathrm{Mp}\left({ }^{\circ} \mathrm{C}\right)$ : 88-90. [73]

\section{2-(1-benzyl-1H-1,2,3-triazol-4-yl)propan-2-ol (4e):}

${ }^{1} \mathrm{HNMR}$ (DMSO, $300 \mathrm{MHz}$ ): $\delta=1.45$ (s, 6H, $\mathrm{CH}_{3}$ ), 5.09 (s, 2H, $\mathrm{CH}_{2}$ ), 5.55 (s, 1H, OH), $7.40(5 \mathrm{H}, \mathrm{H}-\mathrm{Ar}), 7.91(\mathrm{~s}$, $1 \mathrm{H}, \mathrm{CH}$ of triazole) ppm.

Anal. calcd for $\mathrm{C}_{12} \mathrm{H}_{15} \mathrm{~N}_{3} \mathrm{O}: \mathrm{C}, 66.34 ; \mathrm{H}, 6.96 ; \mathrm{N}, 19.34 ; \mathrm{O}, 7.36$; found: $\mathrm{C}, 66.41 ; \mathrm{H}, 7.01 ; \mathrm{N}, 19.41 . \mathrm{Mp}\left({ }^{\circ} \mathrm{C}\right): 75-$ 77. [72] 


\section{2-(1-(4-methylbenzyl)-1H-1,2,3-triazol-4-yl)propan-2-ol (4f):}

${ }^{1} \mathrm{HNMR}$ (DMSO, $\left.300 \mathrm{MHz}\right): \delta=1.44\left(\mathrm{~s}, 6 \mathrm{H}, \mathrm{CH}_{3}\right), 2.30\left(\mathrm{~s}, 3 \mathrm{H}, \mathrm{CH}_{3}\right), 5.09\left(\mathrm{~s}, 2 \mathrm{H}, \mathrm{CH}_{2}\right), 5.49(\mathrm{~s}, 1 \mathrm{H}, \mathrm{OH}), 7.23(5 \mathrm{H}$, $\mathrm{H}-\mathrm{Ar}), 7.87$ (s, 1H, CH of triazole) ppm.

${ }^{13} \mathrm{CNMR}$ (DMSO, $75 \mathrm{MHz}$ ): $\delta=22.90,31.94,58.86,78.40,122.41,125.68,129.38,131.04,133.66,134.80 \mathrm{ppm}$.

Anal. calcd for $\mathrm{C}_{13} \mathrm{H}_{17} \mathrm{~N}_{3} \mathrm{O}: \mathrm{C}, 67.51 ; \mathrm{H}, 7.41 ; \mathrm{N}, 18.17 ; \mathrm{O}, 6.92$; found: $\mathrm{C}, 67.53 ; \mathrm{H}, 7.50 ; \mathrm{N}, 17.98$.

\section{2-(1-(4-chlorobenzyl)-1H-1,2,3-triazol-4-yl)propan-2-ol (4g):}

${ }^{1} \mathrm{HNMR}$ (DMSO, $\left.300 \mathrm{MHz}\right): \delta=1.46\left(\mathrm{~s}, 6 \mathrm{H}, \mathrm{CH}_{3}\right.$ ), $5.13\left(\mathrm{~s}, 2 \mathrm{H}, \mathrm{CH}_{2}\right.$ ), 5.67 (s, 1H, OH), $7.42(4 \mathrm{H}, \mathrm{H}-\mathrm{Ar}), 7.88$ (s, $1 \mathrm{H}, \mathrm{CH}$ of triazole) $\mathrm{ppm}$.

${ }^{13} \mathrm{CNMR}$ (DMSO, $75 \mathrm{MHz}$ ): $\delta=31.17,58.64,78.40,122.41,129.38,130.99,132.19,133.66 \mathrm{ppm}$.

Anal. calcd for $\mathrm{C}_{12} \mathrm{H}_{14} \mathrm{ClN}_{3} \mathrm{O}$ : C, 57.26; H, 5.61; Cl, 14.08; N, 16.69; O, 6.36; found: C, 57.31; H, 5.62; N, 16.82 .

2-(1-(2-chlorobenzyl)-1H-1,2,3-triazol-4-yl)propan-2-ol (4h):

${ }^{1} \mathrm{HNMR}$ (DMSO, $300 \mathrm{MHz}$ ): $\delta=1.46\left(\mathrm{~s}, 6 \mathrm{H}, \mathrm{CH}_{3}\right.$ ), 5.15 (s, 2H, $\mathrm{CH}_{2}$ ), 5.66 (s, 1H, OH), 7.27 (d, 1H, H-Ar), 7.51 (d of d, 1H, H-Ar), 7.63 (d of d, 1H, H-Ar), 7.73 (d, 1H, H-Ar), 7.90 (s, 1H, CH of triazole) ppm.

${ }^{13} \mathrm{CNMR}$ (DMSO, $75 \mathrm{MHz}$ ): $\delta=31.17,52.89,78.40,121.05,127.24,127.25,128.28,130.76,131.04,133.66,139.41$ ppm.

Anal. calcd for $\mathrm{C}_{12} \mathrm{H}_{14} \mathrm{ClN}_{3} \mathrm{O}$ : C, 57.26; H, 5.61; $\mathrm{Cl}, 14.08 ; \mathrm{N}, 16.69 ; \mathrm{O}, 6.36$; found: $\mathrm{C}, 57.34 ; \mathrm{H}, 5.59 ; \mathrm{N}, 16.79$.

\section{1-Phenyl-2-(4-phenyl-1H-1,2,3-triazol-1-yl)ethanone (4i):}

${ }^{1} \mathrm{HNMR}$ (DMSO, $300 \mathrm{MHz}$ ): $\delta=6.29$ (s, 2H, $\mathrm{CH}_{2}$ ), 7.35-7.40 (t, 1H, H-Ar), 7.46-7.68 (m, 4H, H-Ar), 7.75-7.81 (t, 1H, H-Ar), 7.88-7.92 (d, 2H, H-Ar), 8.11-8.15 (d, 2H, H-Ar), 8.55 (s, 1H, CH of triazole) ppm.

${ }^{13} \mathrm{CNMR}$ (DMSO, $\left.75 \mathrm{MHz}\right): \delta=56.49,123.53,125.64,128.36,128.72,129.45,129.51,131.24,134.61,134.79$, $146.78,192.70 \mathrm{ppm} . \mathrm{Mp}\left({ }^{\circ} \mathrm{C}\right): 170-172$ [71].

Anal. calcd for $\mathrm{C}_{16} \mathrm{H}_{13} \mathrm{~N}_{3} \mathrm{O}$ : C, 72.99; H, 4.98; N, 15.96; found: C, 72.67; H, 5.01; N, 15.94. Mp $\left({ }^{\circ} \mathrm{C}\right)$ : 170-172 [71].

1-(4-Bromophenyl)-2-(4-phenyl-1H-1,2,3-triazol-1-yl) ethanone (4j).

${ }^{1} \mathrm{HNMR}$ (DMSO, $300 \mathrm{MHz}$ ): $\delta=6.27$ (s, 2H, $\mathrm{CH}_{2}$ ), 7.35-7.52 (t,t, 3H, H -Ar), 7.85-7.91 (m, 4H, H-Ar), 8.03- 8.07 (d, 2H, H-Ar), 8.33-8.37 (d, 2H, H-Ar), 8.54 (s, 1H, CH of triazole) ppm.

${ }^{13} \mathrm{CNMR}$ (DMSO, $\left.75 \mathrm{MHz}\right): \delta=56.47,121.53,127.54,128.06,128.86,129.82,129.85,130.51,131.54,133.61$, $148.78,192.70 \mathrm{ppm} . \mathrm{Mp}\left({ }^{\circ} \mathrm{C}\right): 116-120$ [71].

Anal. calcd for $\mathrm{C}_{16} \mathrm{H}_{12} \mathrm{BrN}_{3} \mathrm{O}$ : C, 56.16; H, 3.53; N, 12.28 ; found: $\mathrm{C}, 56.24 ; \mathrm{H}, 3.55 ; \mathrm{N}, 12.14 . \mathrm{Mp}\left({ }^{\circ} \mathrm{C}\right): 116-120$ [71].

1-(4-Nitro phenyl)-2-(4-phenyl-1H-1,2,3-triazol-1-yl)ethanone (4k):

${ }^{1} \mathrm{HNMR}$ (DMSO, $300 \mathrm{MHz}$ ): $\delta=6.37$ (s, 2H, $\mathrm{CH}_{2}$ ), 7.35- 7.41 (t, 1H, H-Ar), 7.47-7.52 (t, 2H, H-Ar), 7.89-7.92 (t, 2H, H-Ar), 8.33-8.37 (d, 2H, H-Ar), 8.44-8.48 (d, 2H, H-Ar), 8.55 (s, 1H, CH of triazole) ppm.

${ }^{13} \mathrm{CNMR}$ (DMSO, $75 \mathrm{MHz}$ ): $\delta=56.47,121.23,123.54,128.06,128.76,129.72,129.80,130.41,140.58,148.88$, 150.51, $192.71 \mathrm{ppm}$.

Anal. calcd for $\mathrm{C}_{16} \mathrm{H}_{12} \mathrm{~N}_{4} \mathrm{O}_{3}: \mathrm{C}, 62.33 ; \mathrm{H}, 3.92 ; \mathrm{N}, 18.17$; found: $\mathrm{C}, 61.94 ; \mathrm{H}, 3.62 ; \mathrm{N}, 18.21 . \mathrm{Mp}\left({ }^{\circ} \mathrm{C}\right): 184-185$. [74] 
2-(4-(2-Hydroxypropan-2-yl)-1H-1,2,3-triazol-1-yl)-1- phenylethanone (4l).

${ }^{1} \mathrm{HNMR}$ (DMSO, $300 \mathrm{MHz}$ ): $\delta=1.51\left(\mathrm{~s}, 2 \times 3 \mathrm{H}, \mathrm{CH}_{3}\right.$ ), 5.16 (s, 1H, OH), $6.15\left(\mathrm{~s}, 2 \mathrm{H}, \mathrm{CH}_{2}\right), 7.61-7.66$ (t, 2H, H-Ar), 7.73-7.79 (t, 2H, CH-Ar), 7.86 (s, 1H, CH of triazole), 8.08-8.11 (d,d, 2H, H-Ar) ppm.

${ }^{13}$ CNMR (DMSO, $75 \mathrm{MHz}$ ): $\delta=31.30,56.46,78.32$, 122.92, 128.75, 130.78, 133.14, 133.53, 134.53, 190.90 ppm.

Anal. calcd for $\mathrm{C}_{11} \mathrm{H}_{11} \mathrm{~N}_{3} \mathrm{O}_{2}: \mathrm{C}, 60.82 ; \mathrm{H}, 5.10 ; \mathrm{N}, 19.34$; found: $\mathrm{C}, 60.79 ; \mathrm{H}, 5.13 ; \mathrm{N}, 19.37$. Mp $\left({ }^{\circ} \mathrm{C}\right)$ : 96-98. [74]

1-(4-Bromophenyl)-2-(4-(2-hydroxypropan-2-yl)-1H-1,2,3- triazol-1-yl)ethanone (4m).

${ }^{1} \mathrm{HNMR}$ (DMSO, $\left.300 \mathrm{MHz}\right): \delta=1.51\left(\mathrm{~s}, 6 \mathrm{H}, \mathrm{CH}_{3}\right), 5.16(\mathrm{~s}, 1 \mathrm{H}, \mathrm{OH}), 6.13\left(\mathrm{~s}, 1 \mathrm{H}, \mathrm{CH}_{2}\right), 7.84-7.87(\mathrm{~d}, 3 \mathrm{H}, \mathrm{CH}$ of triazole and $\mathrm{H}-\mathrm{Ar}$ ), 8.00-8.03 (d, 2H, H-Ar) ppm.

${ }^{13} \mathrm{CNMR}$ (DMSO, $75 \mathrm{MHz}$ ): $\delta=31.29,56.50,78.29,122.52,127.32,128.75,129.88,131.54,133.53,152.58,190.91$ ppm. Mp ( $\left.{ }^{\circ} \mathrm{C}\right): 167-169$ [75].

Anal. calcd for $\mathrm{C}_{13} \mathrm{H}_{14} \mathrm{~N}_{4} \mathrm{O}_{4}$ : C, 53.79, H, 4.86; N, 19.30; found: C, 53.63; H, 4.80; N, 19.39 .

2-(4-(2-Hydroxypropan-2-yl)-1H-1,2,3-triazol-1-yl)-1-(4- nitrophenyl)ethanone (4n).

${ }^{1} \mathrm{HNMR}$ (DMSO, $\left.300 \mathrm{MHz}\right): \delta=1.38\left(\mathrm{~s}, 6 \mathrm{H}, \mathrm{CH}_{3}\right), 4.90\left(\mathrm{~s}, 2 \mathrm{H}, \mathrm{CH}_{2}\right), 5.53(\mathrm{~s}, 1 \mathrm{H}, \mathrm{OH}), 7.75(\mathrm{~s}, 1 \mathrm{H}, \mathrm{CH}$ of triazole), 8.31-8.33 (d, d, 2H, H-Ar), 8.41-8.44 (d, 2H, j 1/4 8.7, H-Ar) ppm.

${ }^{13} \mathrm{CNMR}$ (DMSO, $75 \mathrm{MHz}$ ): $\delta=31.18,56.49,78.29,122.82,123.83,129.75,131.24,140.58,152.58,190.90 \mathrm{ppm}$.

Anal. calcd for $\mathrm{C}_{13} \mathrm{H}_{14} \mathrm{~N}_{4} \mathrm{O}_{4}$ : C, 53.79, $\mathrm{H}, 4.86 ; \mathrm{N}, 19.30$; found: $\mathrm{C}, 53.63 ; \mathrm{H}, 4.80 ; \mathrm{N}, 19.39$. Mp ( $\left.{ }^{\circ} \mathrm{C}\right)$ : 126-128 [74].

2-(4-(Hydroxymethyl)-1H-1,2,3-triazol-1-yl)-1- phenylethanone (40).

${ }^{1} \mathrm{HNMR}$ (DMSO, $\left.300 \mathrm{MHz}\right): \delta=4.58-4.59\left(\mathrm{~d}, 2 \mathrm{H}, \mathrm{CH}_{2}-\mathrm{OH}\right), 5.23-5.27(\mathrm{t}, 1 \mathrm{H}, \mathrm{OH}), 6.18\left(\mathrm{~s}, 2 \mathrm{H}, \mathrm{CH}_{2}\right), 7.60-7.66$ (t, 2H, H-Ar), 7.73-7.79 (t, 1H, H-Ar), 7.95 (s, 1H, CH of triazole), 8.08-8.11 (d, 2H, H-Ar) ppm.

${ }^{13} \mathrm{CNMR}$ (DMSO, $75 \mathrm{MHz}$ ): $\delta=55.57,56.20,124.87,128.64,129.47,134.67,148.41,192.76 \mathrm{ppm}$.

Anal. calcd for $\mathrm{C}_{11} \mathrm{H}_{11} \mathrm{~N}_{3} \mathrm{O}_{2}$ : C, 60.82; H, 5.10; N, 19.34; found: C, 60.79; H, 5.13; N, 19.37. Mp ( $\left.{ }^{\circ} \mathrm{C}\right)$ : 111-113 [75].

1-(4-Bromophenyl)-2-(4-(hydroxymethyl)-1H-1,2,3-triazol-1- yl)ethanone (4p).

${ }^{1} \mathrm{HNMR}$ (DMSO, $300 \mathrm{MHz}$ ): $\delta=4.38$ (s, 2H, $\mathrm{CH}_{2}$ ), 5.00 (s, 2H, $\left.\mathrm{CH}_{2}-\mathrm{OH}\right), 5.75(\mathrm{~s}, 1 \mathrm{H}, \mathrm{OH}), 7.98(\mathrm{~s}, 1 \mathrm{H}, \mathrm{CH}$ of triazole), 8.33-8.37 (d, 2H, H-Ar), 8.44-8.48 (d, 2H, H-Ar) ppm.

${ }^{13} \mathrm{CNMR}$ (DMSO, $75 \mathrm{MHz}$ ): $\delta=55.57,56.20,122.77,127.72,129.47,131.41,134.67,147.41,192.76 \mathrm{ppm}$.

Anal. calcd for $\mathrm{C}_{11} \mathrm{H}_{10} \mathrm{BrN}_{3} \mathrm{O}_{2}$ : C, 44.62; H, 3.40; $\mathrm{Br}, 26.98 ; \mathrm{N}, 14.19$; found: $\mathrm{C}, 44.48 ; \mathrm{H}, 3.44 ; \mathrm{N}, 14.21$. Mp $\left({ }^{\circ} \mathrm{C}\right)$ : $156-158$ [74].

\section{Result and discussion}

\section{2) Catalyst characterization}

We synthesized a catalyst that is very efficient, selectivity, green and suitable for the synthesis of triazole derivatives under aqueous conditions, because organic reaction design in aqueous environments is another project of progress in green chemistry. Finally, with the help of an external magnet, the catalyst can be removed from the reaction medium with high efficiency and reused. A general schematic for the synthesis of $\mathrm{Fe}_{3} \mathrm{O}_{4} @$ Pectin@ $\left(\mathrm{CH}_{2}\right)_{3}-\mathrm{Acetamide}-\mathrm{Cu}(\mathrm{II})$ is shown (Scheme 1).

Using FT-IR spectroscopy to investigate the steps of catalyst synthesis and confirm the formation of the expected functional groups has been done. The spectra of $\mathrm{Fe}_{3} \mathrm{O}_{4}$ (a), Pectin (b), $\mathrm{Fe}_{3} \mathrm{O}_{4} @$ Pectin (c), $\mathrm{Fe}_{3} \mathrm{O}_{4} @$ Pectin@ $\mathrm{APTES}$ (d), 
$\mathrm{Fe}_{3} \mathrm{O}_{4} @$ Pectin@ $\left(\mathrm{CH}_{2}\right)_{3}$-Acetamide (e) and $\mathrm{Fe}_{3} \mathrm{O}_{4} @$ Pectin@ $\left(\mathrm{CH}_{2}\right)_{3}$-Acetamide-Cu(II) nanocomposites (f) are shown in Figure 1. FT-IR spectrum of $\mathrm{Fe}_{3} \mathrm{O}_{4}$ (Fig. 1a) the stretching vibrations $\mathrm{Fe}-\mathrm{O}$ and $\mathrm{O}-\mathrm{H}$ at $574 \mathrm{~cm}^{-1}$ and $3420 \mathrm{~cm}^{-1}$ that allow the establishment of $\mathrm{Fe}_{3} \mathrm{O}_{4}$ nanoparticles. The FT-IR spectrum of Pectin (Fig. 1b) shows characteristic peaks at $3400-3600 \mathrm{~cm}^{-1}$ (O-H stretching alcoholic and acidic), $2923 \mathrm{~cm}^{-1}$ (C-H stretching), $1725 \mathrm{~cm}^{-1}$ (C=O of ester), 1618 $\mathrm{cm}^{-1}$ ( $\mathrm{COO}^{-}$asymmetric stretching), $1412 \mathrm{~cm}^{-1}$ ( $\mathrm{COO}^{-}$symmetric stretching). After core-shell, the Pectin with $\mathrm{Fe}_{3} \mathrm{O}_{4}$ shows the peaks at $3422 \mathrm{~cm}^{-1}$ (O-H stretching), $2923 \mathrm{~cm}^{-1}$ (C-H stretching), $1626 \mathrm{~cm}^{-1}$ ( $\mathrm{COO}^{-}$asymmetric stretching) and $577 \mathrm{~cm}^{-1}$ cans be assigned to $\mathrm{Fe}_{3} \mathrm{O}_{4}$ (Fig. 1c). As predicted (Fig. 1d), several new bands have been detected in 1100,1200 and $3200 \mathrm{~cm}^{-1}$ that were corresponding to the stretching vibrations of the C-N, Si-O functional group and $\mathrm{NH}_{2}$ (that overlap with peaks of $\mathrm{OH}$ in pectin) bond that approval of surfaces chemical modification of the $\mathrm{Fe}_{3} \mathrm{O}_{4} @$ pectin with the (3-Aminopropyl) triethoxysilane. FT-IR spectrum Of $\mathrm{Fe}_{3} \mathrm{O}_{4} @$ Pectin@ $\left(\mathrm{CH}_{2}\right)_{3}$-Acetamide nanoparticles (Fig. 1e), the presence of a weak peak of $1650 \mathrm{~cm}^{-1}$, which is covered by peaks of carbonyl group of pectin and peaks of $\mathrm{NH}_{2}$, overlap with peaks of $\mathrm{OH}$ in pectin, indicates the formation of a Schiff base in the structure of this catalyst. In the FT-IR spectrum of the $\mathrm{Fe}_{3} \mathrm{O}_{4} @ P e c t i n @\left(\mathrm{CH}_{2}\right)_{3}$-Acetamide-Cu(II), the shifting of the stretching vibration of the $\mathrm{C}=\mathrm{N}$ groups to lower wave-number confirms the coordination of $\mathrm{Cu}$ metal ions to the nitrogen atoms of the Schiff base.

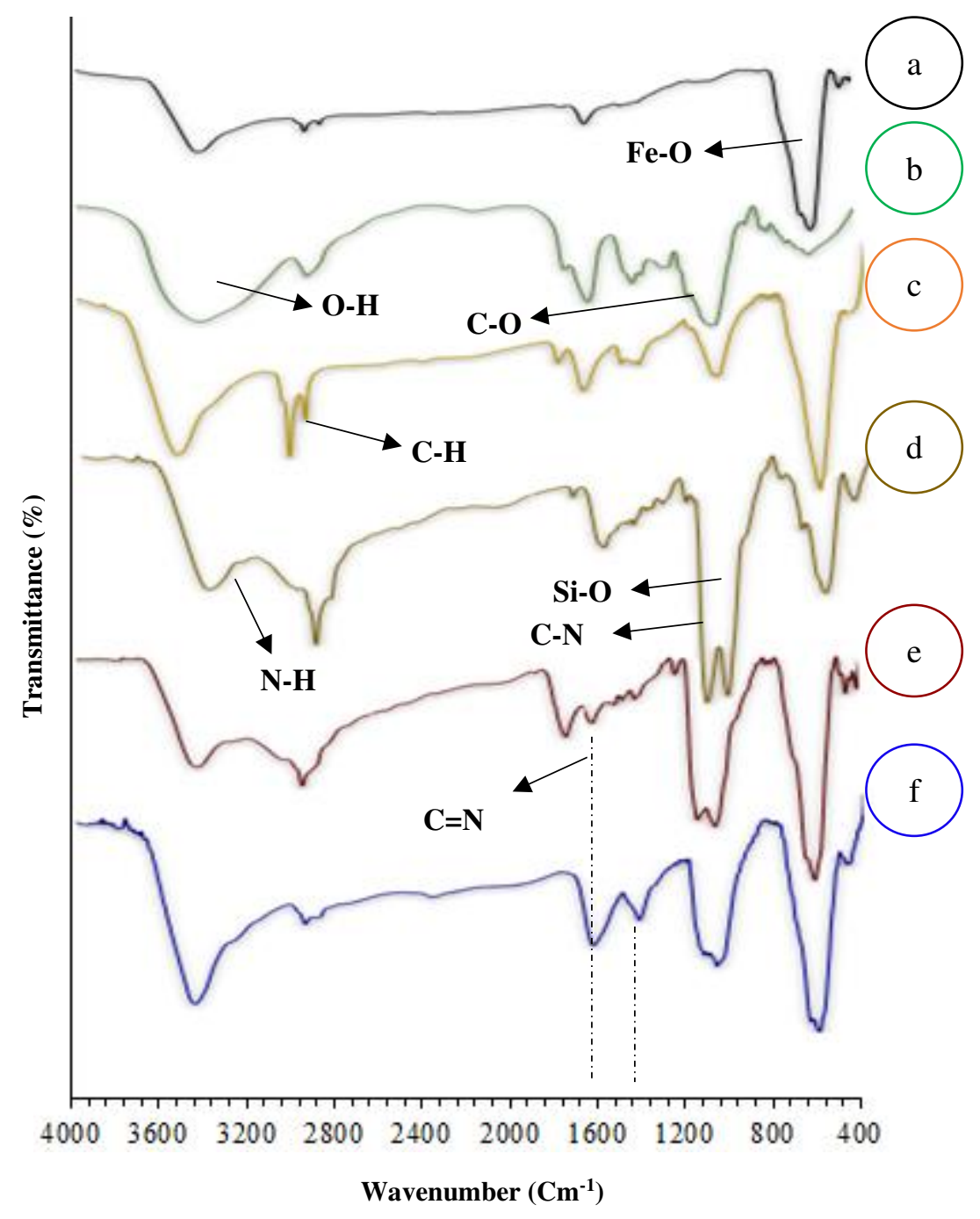

Fig. 1: FT-IR spectra of a) $\mathrm{Fe}_{3} \mathrm{O}_{4}$, b) Pectin, c) $\mathrm{Fe}_{3} \mathrm{O}_{4} @$ Pectin, d) $\mathrm{Fe}_{3} \mathrm{O}_{4} @$ Pectin@APTES, e) $\mathrm{Fe}_{3} \mathrm{O}_{4} @ \mathrm{Pectin} @\left(\mathrm{CH}_{2}\right)_{3}-$ Acetamide, f) $\mathrm{Fe}_{3} \mathrm{O}_{4} @$ Pectin@ $\left(\mathrm{CH}_{2}\right)_{3}$-Acetamide- $\mathrm{Cu}(\mathrm{II})$ 
The TEM method was used to gain further insight into the structure of $\mathrm{Fe}_{3} \mathrm{O}_{4} @ \mathrm{Pectin} @\left(\mathrm{CH}_{2}\right)_{3}$-Acetamide-Cu(II) nanostructures. Monodispersed nanoparticles were identified with a relatively uniform morphology (Fig. 2). The average diameter of nanostructures is obtained based on the $15 \mathrm{~nm}$ particle size distribution histogram (Fig. 2).
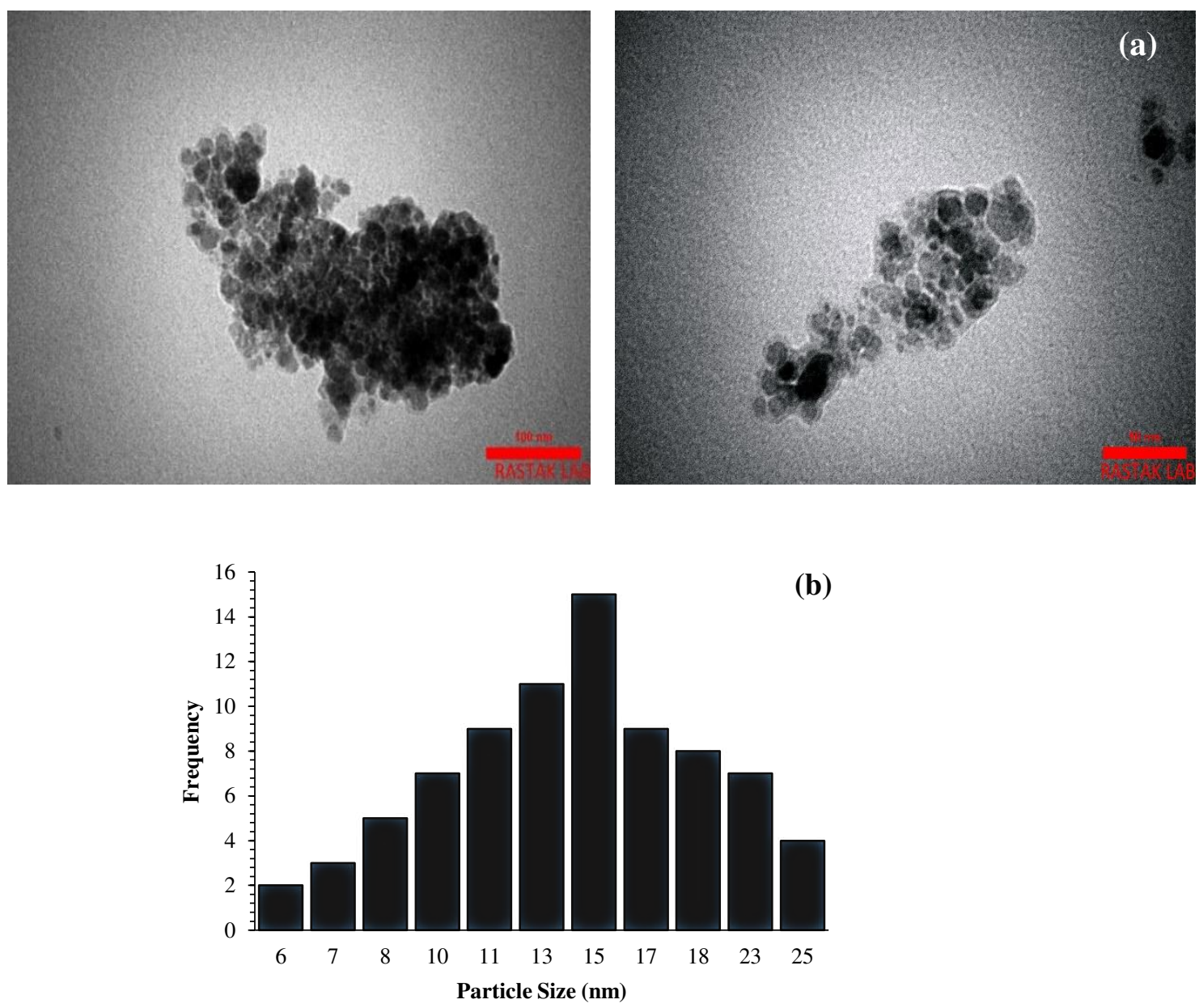

Fig. 2: TEM images (a) Particle size distribution histogram (b) of the $\mathrm{Fe}_{3} \mathrm{O}_{4} @$ Pectin@ $\left(\mathrm{CH}_{2}\right)_{3}-\mathrm{Acetamide}-\mathrm{Cu}(\mathrm{II})$

The thermal degradation behavior of $\mathrm{Fe}_{3} \mathrm{O}_{4} @$ Pectin@ $\left(\mathrm{CH}_{2}\right)_{3}$-Acetamide-Cu(II) catalyst was investigated by TGA analysis, and its curve is shown in Figure 3 that there are three thermal stages. In the first stage that occurs at temperatures of 50 to $100^{\circ} \mathrm{C}$, mass loss of about $4 \%$ due to the desorption of water molecules in the nanocatalyst surface. The second stage, which weight loss of about $10 \%$, occurs in the temperature range of 200 to $350^{\circ} \mathrm{C}$, is related to the major degradation of pectin, because pure pectin is degraded at a temperature of 300 to $500{ }^{\circ} \mathrm{C}$. The third stage of the weight loss of $8 \%$ in the temperature range between 330 and $630{ }^{\circ} \mathrm{C}$ may be due to the thermal crystal phase alteration from $\mathrm{Fe}_{3} \mathrm{O}_{4}$ to $\gamma-\mathrm{Fe}_{2} \mathrm{O}_{3}$. Other stages of the weight loss of about $11 \%$ at the temperature with a gentle slope of $400-800{ }^{\circ} \mathrm{C}$ were assigned due to the decomposition of the immobilized organic moieties on the surface of the $\mathrm{Fe}_{3} \mathrm{O}_{4} @$ Pectin core-shell nanoparticles. 


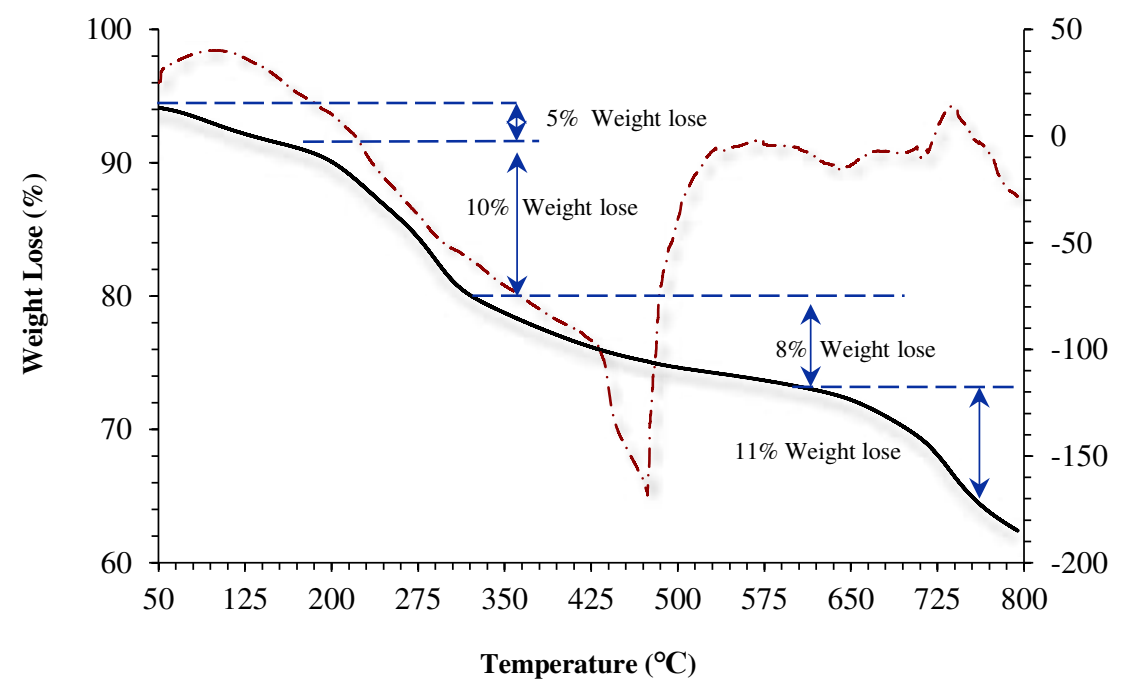

Fig. 3: The TGA curve of the $\mathrm{Fe}_{3} \mathrm{O}_{4} @ P e c t i n @\left(\mathrm{CH}_{2}\right)_{3}$-Acetamide- $\mathrm{Cu}$ (II)

The Field Emission Scanning Electron Microscopy image and Energy Dispersive X-Ray analysis of $\mathrm{Fe}_{3} \mathrm{O}_{4} @$ Pectin@ $\left(\mathrm{CH}_{2}\right)_{3}$-Acetamide-Cu(II) were characterized by FESEM and EDX (Fig. 4). FESEM analysis of products (Fig. 4a) provides information on the size and morphology of $\mathrm{Fe}_{3} \mathrm{O}_{4} @$ Pectin@ $\left(\mathrm{CH}_{2}\right)_{3}$-Acetamide- $\mathrm{Cu}(\mathrm{II})$. The results showed the average product size of $\mathrm{Fe}_{3} \mathrm{O}_{4} @ P e c t i n @\left(\mathrm{CH}_{2}\right)_{3}$-Acetamide-Cu(II) nanoparticles was less than $24 \mathrm{~nm}$. By EDX analyzing, the distribution of elements in $\mathrm{Fe}_{3} \mathrm{O}_{4} @ P e c t i n @\left(\mathrm{CH}_{2}\right)_{3}$-Acetamide- $\mathrm{Cu}$ (II) were studied (Fig. 4b). As can be seen, elements of $\mathrm{Fe}, \mathrm{Si}, \mathrm{O}, \mathrm{C}, \mathrm{N}$, and $\mathrm{Cu}$ are present in the structure of the catalyst, indicating that our catalyst is well synthesized.
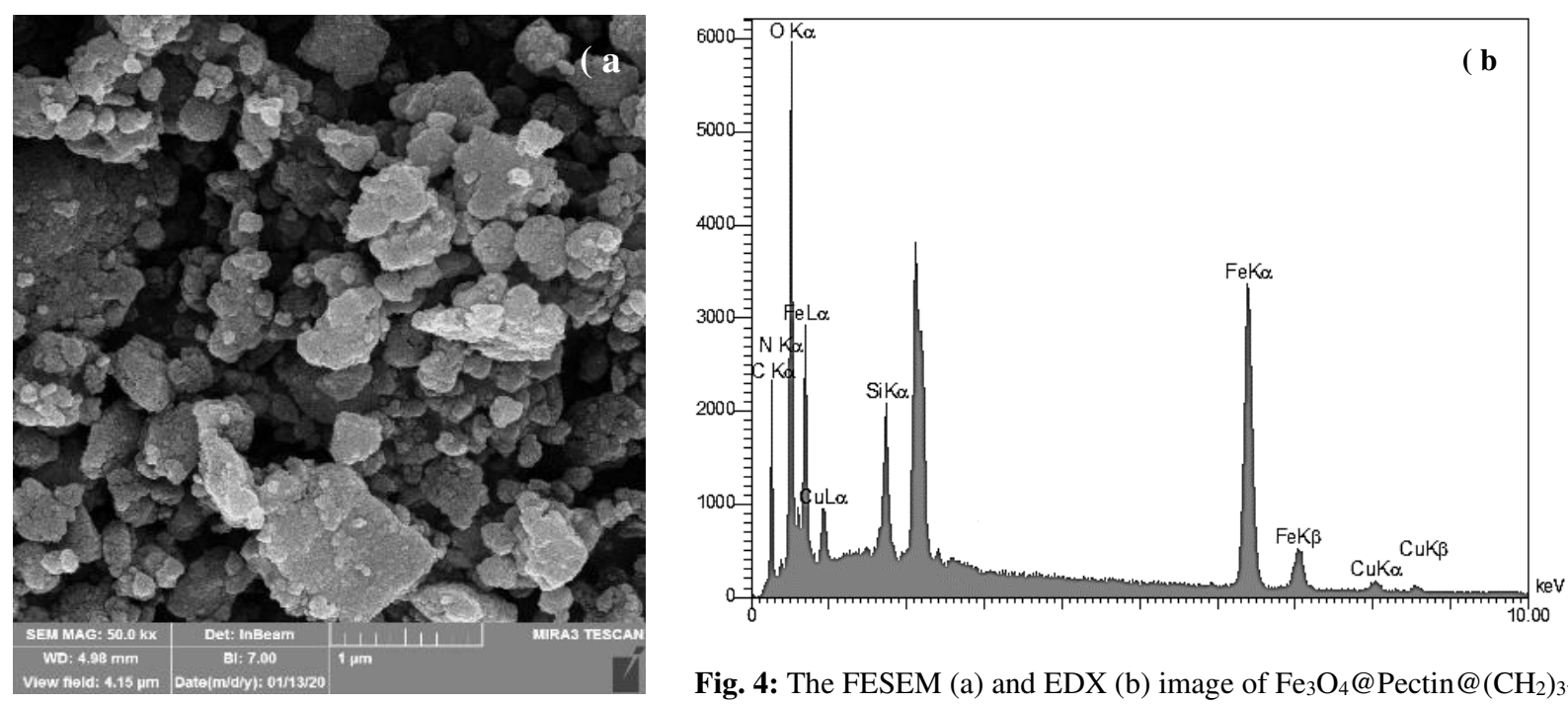

Fig. 4: The FESEM (a) and EDX (b) image of $\mathrm{Fe}_{3} \mathrm{O}_{4} @ P e c t i n @\left(\mathrm{CH}_{2}\right)_{3}-$ Acetamide- $\mathrm{Cu}(\mathrm{II})$

The magnetic properties of $\mathrm{Fe}_{3} \mathrm{O}_{4}$ (Fig. 5a), $\mathrm{Fe}_{3} \mathrm{O}_{4} @$ Pectin (Fig. 5b) and $\mathrm{Fe}_{3} \mathrm{O}_{4} @$ Pectin $@\left(\mathrm{CH}_{2}\right)_{3}$-Acetamide-Cu(II) nanoparticles (Fig. 5c) were recorded at room temperature using the VSM method (Fig. 5). 63.23, 53.23 and 36.93 emu/g were the saturation magnetization values for $\mathrm{Fe}_{3} \mathrm{O}_{4}, \mathrm{Fe}_{3} \mathrm{O}_{4} @$ Pectin and $\mathrm{Fe}_{3} \mathrm{O}_{4} @$ Pectin $@\left(\mathrm{CH}_{2}\right)_{3}$-Acetamide$\mathrm{Cu}$ (II) nanoparticles. Therefore the saturation magnetization value of $\mathrm{Fe}_{3} \mathrm{O}_{4}$ after coating with pectin, APTMS and acetamide $\left(\mathrm{Fe}_{3} \mathrm{O}_{4} @\right.$ Pectin@ $\left(\mathrm{CH}_{2}\right)_{3}$-Acetamide-Cu(II)) decreases significantly from about $63.23 \mathrm{emu} / \mathrm{g}$ to 36.93 
emu/g. The pectin shell that surrounds the $\mathrm{Fe}_{3} \mathrm{O}_{4}$ nanoparticles reduce the interactions between these particles. However, despite the decrease in saturation magnetism, the catalyst can still be rapidly and easily removed from the reaction media using an external magnetic field.

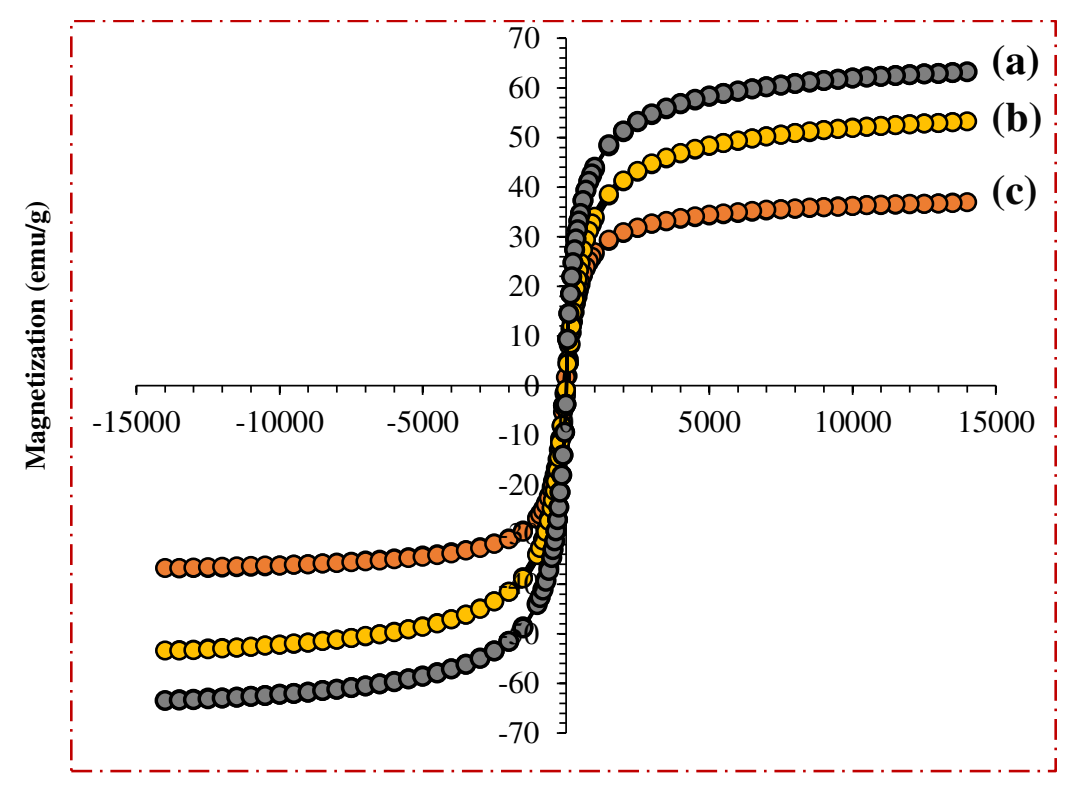

Applied field (Oe)

Fig. 5: The magnetic properties of a) $\mathrm{Fe}_{3} \mathrm{O}_{4}$ b) $\mathrm{Fe}_{3} \mathrm{O}_{4} @$ Pectin c) $\mathrm{Fe}_{3} \mathrm{O}_{4} @ P e c t i n @\left(\mathrm{CH}_{2}\right)_{3}-\mathrm{Acetamide}-\mathrm{Cu}(\mathrm{II})$

X-ray diffraction patterns of $\mathrm{Fe}_{3} \mathrm{O}_{4}, \mathrm{CuO}$, and $\mathrm{Fe}_{3} \mathrm{O}_{4} @ P e c t i n @\left(\mathrm{CH}_{2}\right)_{3}$-Acetamide- $\mathrm{Cu}(\mathrm{II})$ in the $2 \theta$ range between $10^{\circ}$ and $80^{\circ}$ are shown in Figure 6. The XRD pattern of $\mathrm{Fe}_{3} \mathrm{O}_{4}$ shows six characteristic diffraction peaks according to the cubic crystal system at $30.3^{\circ}, 35.8^{\circ}, 43.6^{\circ}, 54.8^{\circ}, 57.3^{\circ}$, and $63.2^{\circ}(2 \theta)$, corresponded respectively to the (220), (311), (400), (422), (511), and (440) miller indices, according to the database of maghemite (See Fig. 7)[67,68]. Also, the XRD pattern of the $\mathrm{CuO}$ (Fig. 7) shows the peaks at $2 \theta=32.07^{\circ}, 35.47^{\circ}, 35.82^{\circ}, 48.72^{\circ}, 52.97^{\circ}, 58.02^{\circ}, 62.47^{\circ}, 67.87^{\circ}$ and $69.32^{\circ}$ corresponding to the (110), (111), (022), (202), (202), (113), (022), (220) and (222) crystallographic phases in PXRD pattern are related to $\mathrm{CuO}$.[69,70] The XRD pattern of $\mathrm{Fe}_{3} \mathrm{O}_{4} @$ Pectin@ $\left(\mathrm{CH}_{2}\right)_{3}$-Acetamide-Cu(II) was also examined as shown in Figure 7 that matches well with the characteristic peaks of bare $\mathrm{Fe}_{3} \mathrm{O}_{4}$ and $\mathrm{CuO}$, these explanations, these results imply that the spinel structure of $\mathrm{Fe}_{3} \mathrm{O}_{4}$ and $\mathrm{Cu}(\mathrm{II})$ has been retained during the process of catalyst preparation. Also, the peak at $18^{\circ}$, which is related to pectin in $\mathrm{Fe}_{3} \mathrm{O}_{4} @ P e c t i n @\left(\mathrm{CH}_{2}\right)_{3}-\mathrm{Acetamide}-\mathrm{Cu}(\mathrm{II})$, indicates that it is also present in the structure of the pectin catalyst[67]. 


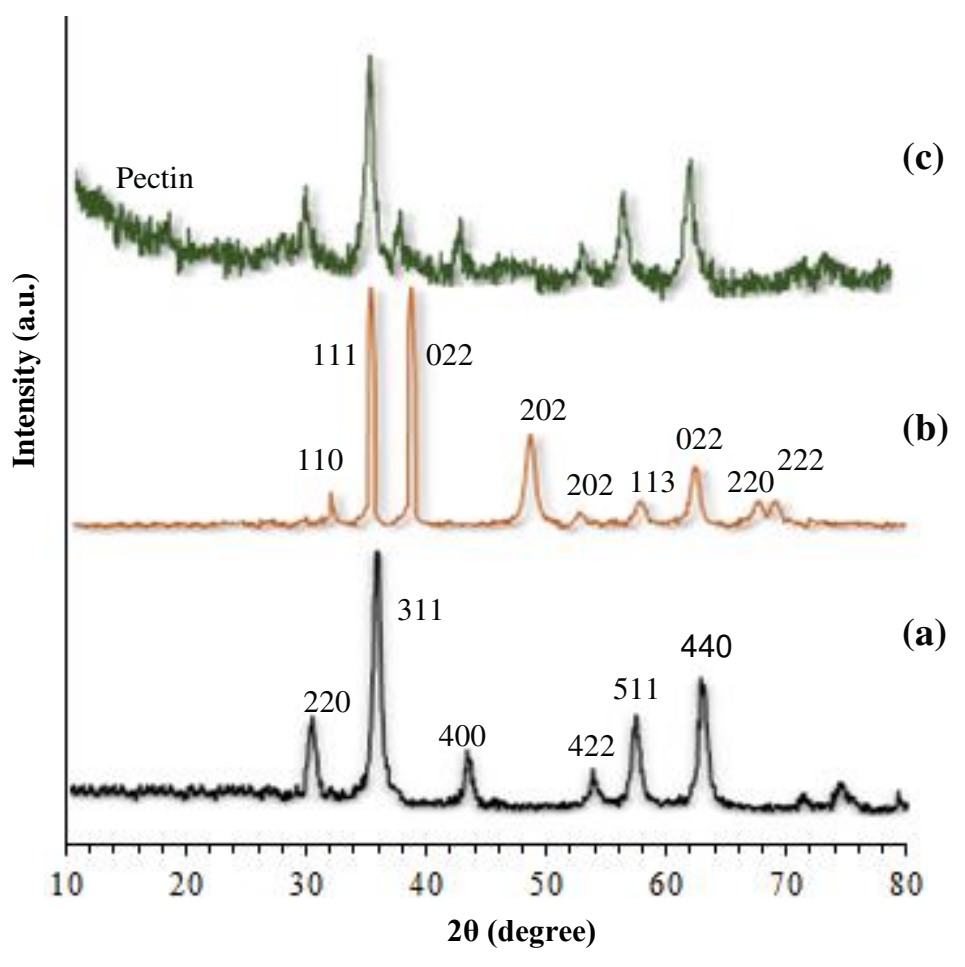

Fig. 6 : XRD of a) $\mathrm{Fe}_{3} \mathrm{O}_{4}$ b) $\mathrm{CuO}$ c) $\mathrm{Fe}_{3} \mathrm{O}_{4} @$ Pectin@ $\left(\mathrm{CH}_{2}\right)_{3}-\mathrm{Acetamide}-\mathrm{Cu}$ (II)

\subsection{Evaluation of the catalytic actuality of $\mathrm{Fe}_{3} \mathrm{O}_{4} @ P e c t i n @\left(\mathrm{CH}_{2}\right)_{3}$-Acetamide- $\mathrm{Cu}$ (II) in the reactions of synthesis of triazole derivatives}

The catalytic activity of $\mathrm{Fe}_{3} \mathrm{O}_{4} @$ Pectin@ $\left(\mathrm{CH}_{2}\right)_{3}$-Acetamide-Cu(II) nanocatalysts in the synthesis of 1,2,3-triazole derivatives were investigated. The reaction of benzyl chloride, sodium azide and phenyl acetylene in the presence of $\mathrm{Fe}_{3} \mathrm{O}_{4} @$ Pectin@ $\left(\mathrm{CH}_{2}\right)_{3}$-Acetamide-Cu(II) catalyst was selected as a model. The effect of different parameters on the catalytic activity of $\mathrm{Fe}_{3} \mathrm{O}_{4} @$ Pectin@ $\left(\mathrm{CH}_{2}\right)_{3}$-Acetamide- $\mathrm{Cu}(\mathrm{II})$ was investigated. Reactions were performed with various solvents such as ethanol, methanol, $\mathrm{H}_{2} \mathrm{O}$, n-Hexane and in solvent-free conditions (Fig. 7-I). Ethanol and methanol showed moderate activity, whereas solvent-free and $n$-Hexane were not suitable for this reaction. Further investigation of solvents showed that when used $\mathrm{H}_{2} \mathrm{O}$ as a solvent, the yield of the desired product increases significantly. Therefore, water, which is the cheapest, safest, and environmentally green solvent, is the best choice for this reaction. Then the effect of the amount of catalyst was investigated. The reaction was performed at different levels of the amount of catalyst at $75{ }^{\circ} \mathrm{C}$ (Fig. 7-II). $0.5 \mathrm{~mol} \%$ of the amount catalyst was most effective in providing high yield. Increasing the amount of catalyst decreased the reaction efficiency even after a longer reaction time. Also, the product was not obtained when the reaction was performed without the presence of catalyst. In the next step, the effect of temperature on the reaction was investigated (Fig. 7-III). At room temperature no improvement was observed, however, the best efficiency was observed at $65{ }^{\circ} \mathrm{C}$. After several experimental optimizations, the optimal reaction conditions for the synthesis of 1,2,3- triazole derivatives are as follows: $0.5 \mathrm{~mol} \%$ of catalyst in $\mathrm{H}_{2} \mathrm{O}$ and $65^{\circ} \mathrm{C}$. 


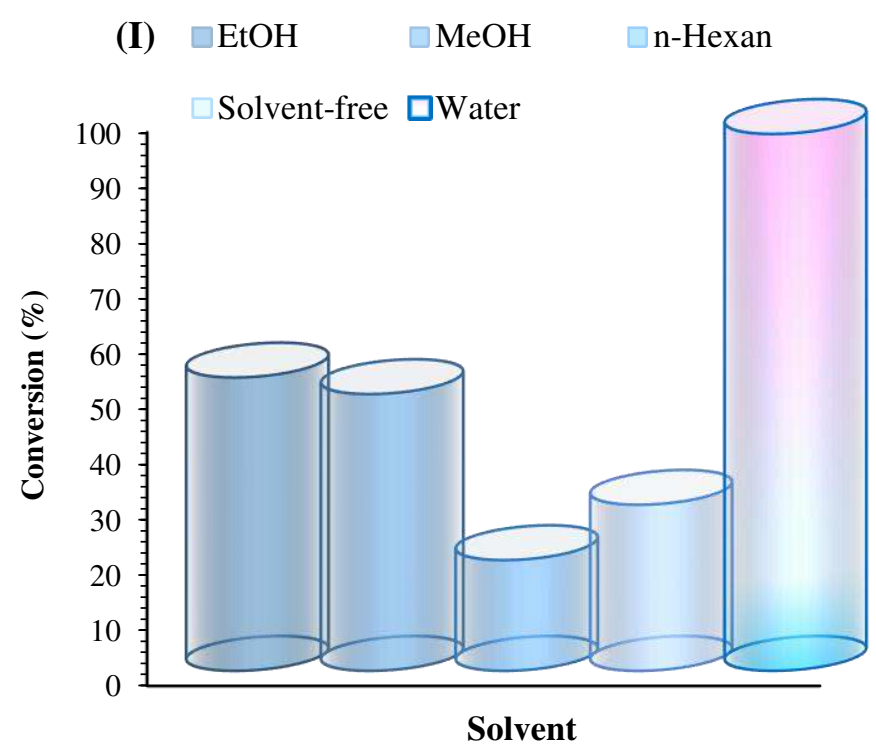

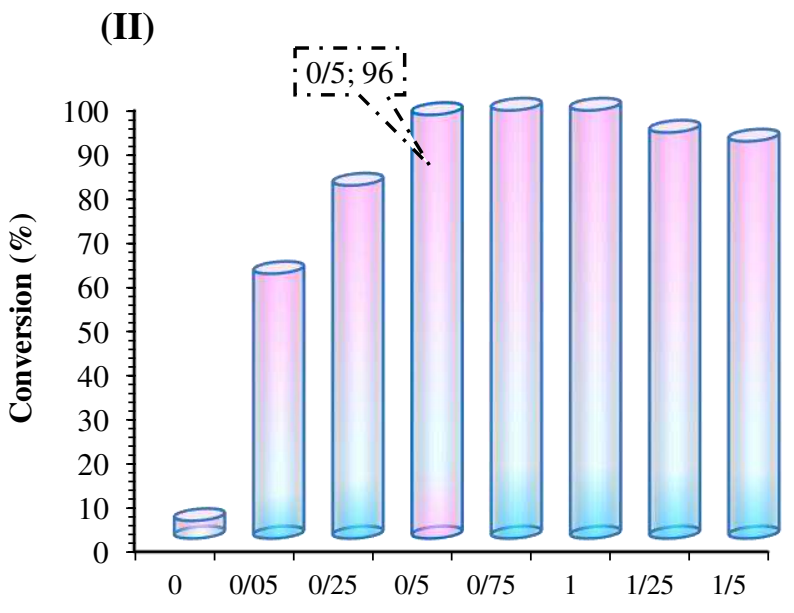

The amount of catalyst (mol\%)
(III)

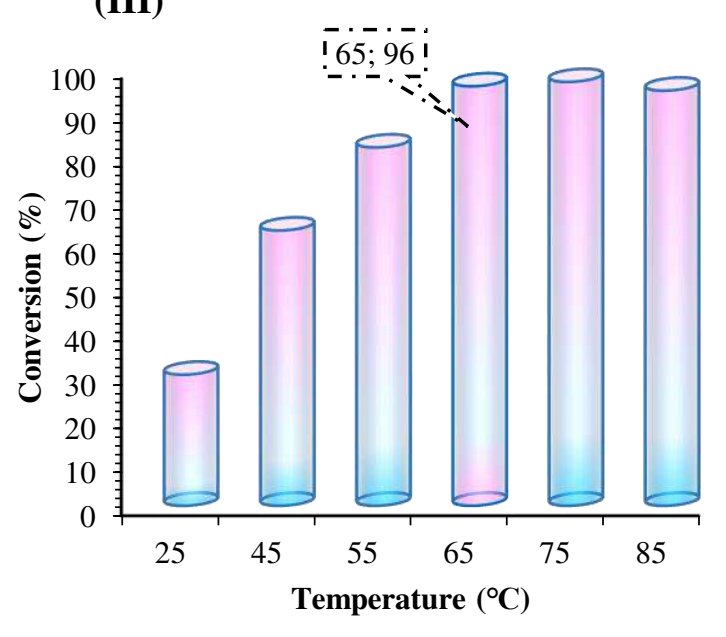

Fig. 7: Screening of solvent, amount catalyst, and temperature for click reaction with a molar ratio of benzyl chloride, sodium azide, phenylacetylene and $\mathrm{Fe}_{3} \mathrm{O}_{4} @$ Pectin@ $\left(\mathrm{CH}_{2}\right)_{3}$-Acetamide- $\mathrm{Cu}(\mathrm{II})$ as catalyst

After determining the optimized reaction conditions, the general use of the $\mathrm{Fe}_{3} \mathrm{O}_{4} @ \mathrm{Pectin} @\left(\mathrm{CH}_{2}\right)_{3}$-Acetamide-Cu(II) catalytic system with different aryl or alkyl halides and alkynes for the synthesis of 1,2,3-triazole derivatives was studied. Reactions of benzyl chloride with sodium azide and phenylacetylene afforded the corresponding triazoles in high to excellent yields (Table 1, entries 1-4). Also, reactions of benzyl chloride with aliphatic alkynes required longer reaction times than aromatic alkynes to give high yields of the corresponding cycloaddition reactions (Table 1, entries $5,6)$. Furthermore, the reaction of phenacyl bromide with alkynes, like benzyl chloride, proceeded well and provided the corresponding products at 87-98 \% isolated yields (Table 1, entries 7-14). Generally, all the substrates had the related products in high yields, But the benzyl chloride and phenacyl bromide with electron-donating substituents (such as methyl) or no substituents, have higher reaction efficiencies than benzyl chloride and phenacyl bromide with electron-withdrawing substituents. 


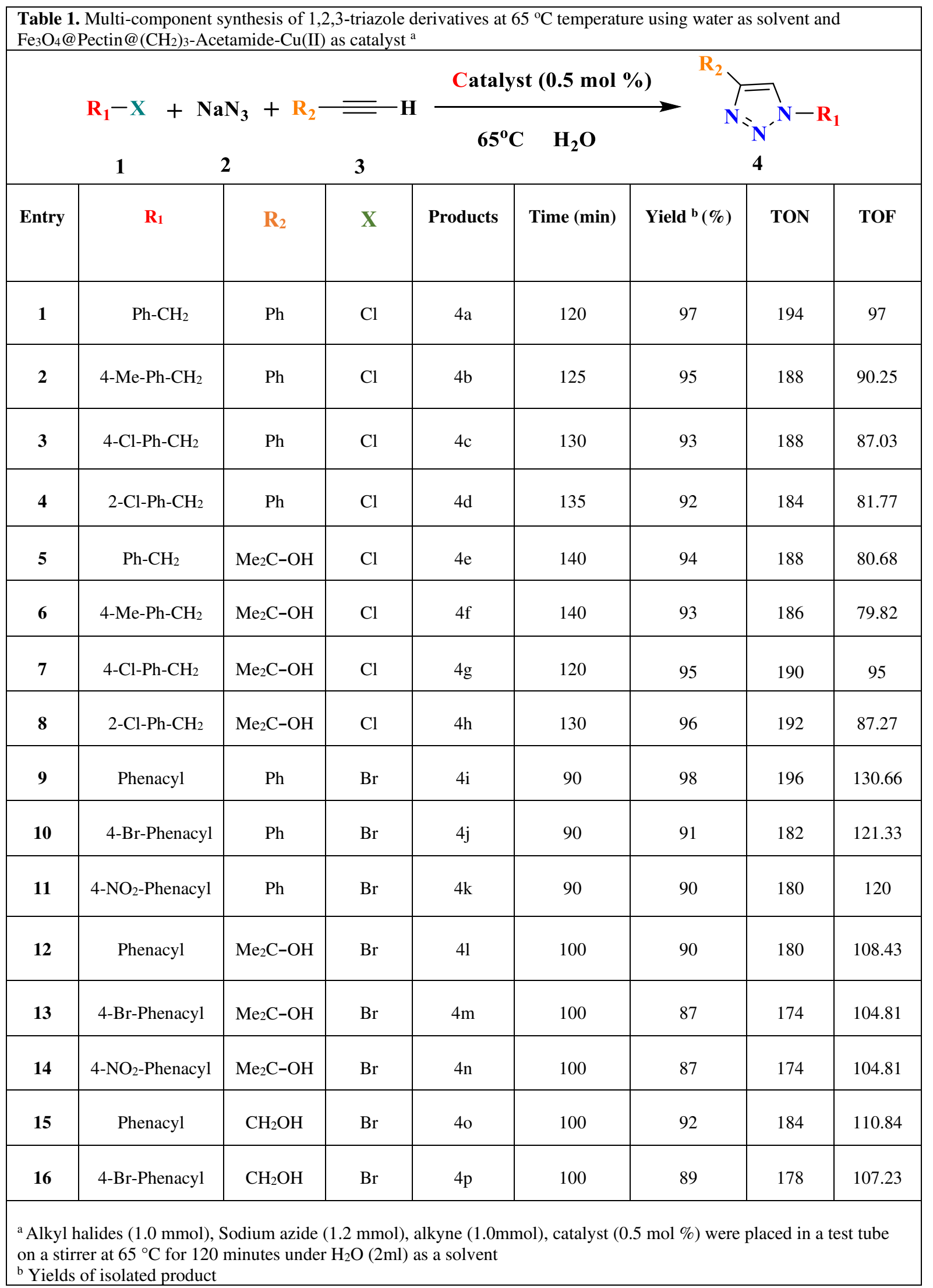


Also, to confirm the performance of the catalyst in comparison with its components, the efficiency of $\mathrm{Fe}_{3} \mathrm{O}_{4}, \mathrm{Pectin}$ $\mathrm{Fe}_{3} \mathrm{O}_{4} @$ Pectin and $\mathrm{Fe}_{3} \mathrm{O}_{4} @ P e c t i n @\left(\mathrm{CH}_{2}\right)_{3}$-Acetamide-Cu(II) were separately studied in the model reaction (Fig. 8).As shown in Figure 8, no product was gained by using $\mathrm{Fe}_{3} \mathrm{O}_{4}$, Pectin and $\mathrm{Fe}_{3} \mathrm{O}_{4} @$ Pectin species. However, in the presence of $\mathrm{Fe}_{3} \mathrm{O}_{4} @ P e c t i n @\left(\mathrm{CH}_{2}\right)_{3}$-Acetamide-Cu(II), the reaction efficiency was very favorable. These findings indicate that the efficiency and strength of the catalyst increase with the presence of copper metal.

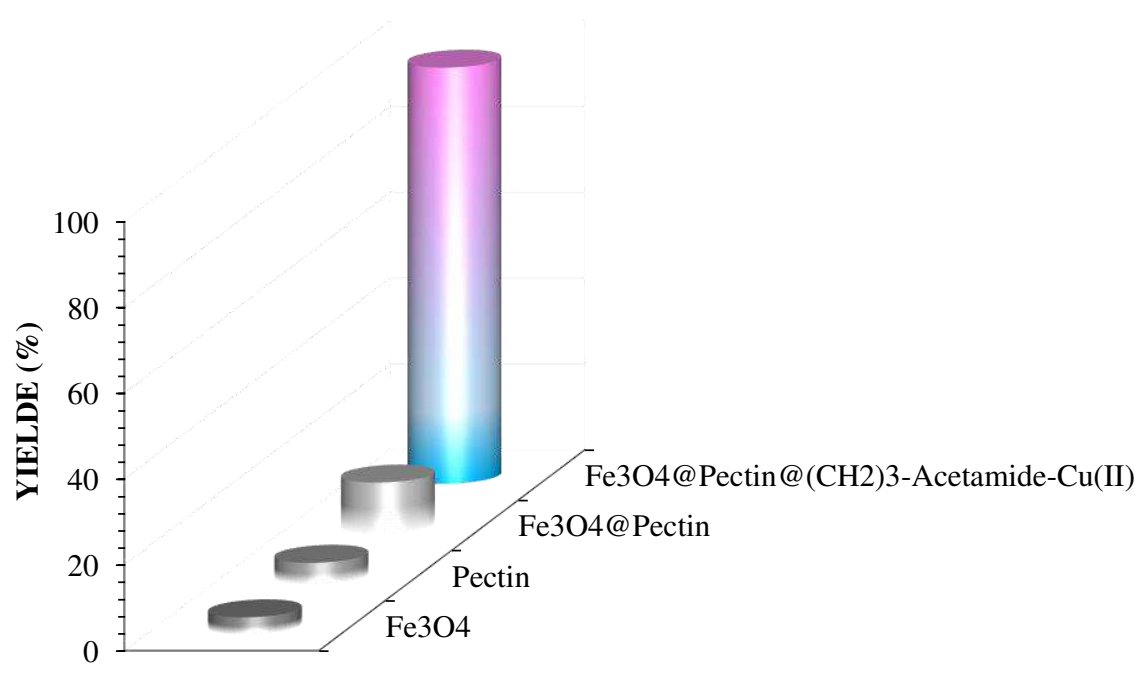

Fig. 8: Comparison of the performance of catalysts with each other. Reaction conditions: Benzyl chloride (1.0 mmol), Sodium azide $(1.2 \mathrm{mmol})$, phenylacetylene $(1.0 \mathrm{mmol})$, catalyst $(0.5 \mathrm{~mol} \%), \mathrm{H}_{2} \mathrm{O}(2 \mathrm{ml})$ as a solvent at $65^{\circ} \mathrm{C}$ for 120 minutes.

Based on previous reports [76] and our observations, a suggested mechanism for the synthesis of triazole derivatives catalyzed by $\mathrm{Fe}_{3} \mathrm{O}_{4} @$ Pectin @ $\left(\mathrm{CH}_{2}\right)_{3}$-Acetamide-Cu(II) nanocatalyst is shown in Scheme3. In the first step, $\mathrm{Cu}-$ acetylide complex was generated from the reaction of $\mathrm{Cu}$ and aryl acetylene (step 1). Then, the alkyl or benzyl azide preparation in situ from sodium azide and alkyl halide [in situ formation (Step 2A)] is attached to [Cu] acetylide and a $\pi$-complex is formed as an intermediate product (step 2B). In the next step, the distal nitrogen of the azide attacks to the carbon of the $\mathrm{Cu}$-acetylide to give a six-membered metallacycle (step 3). Finally, ring contraction to a $\mathrm{Cu}-$ triazolide complex (step 4) is followed by protonolysis that delivers the target product along with regeneration of $\mathrm{Cu}$ catalyst (step 5). 


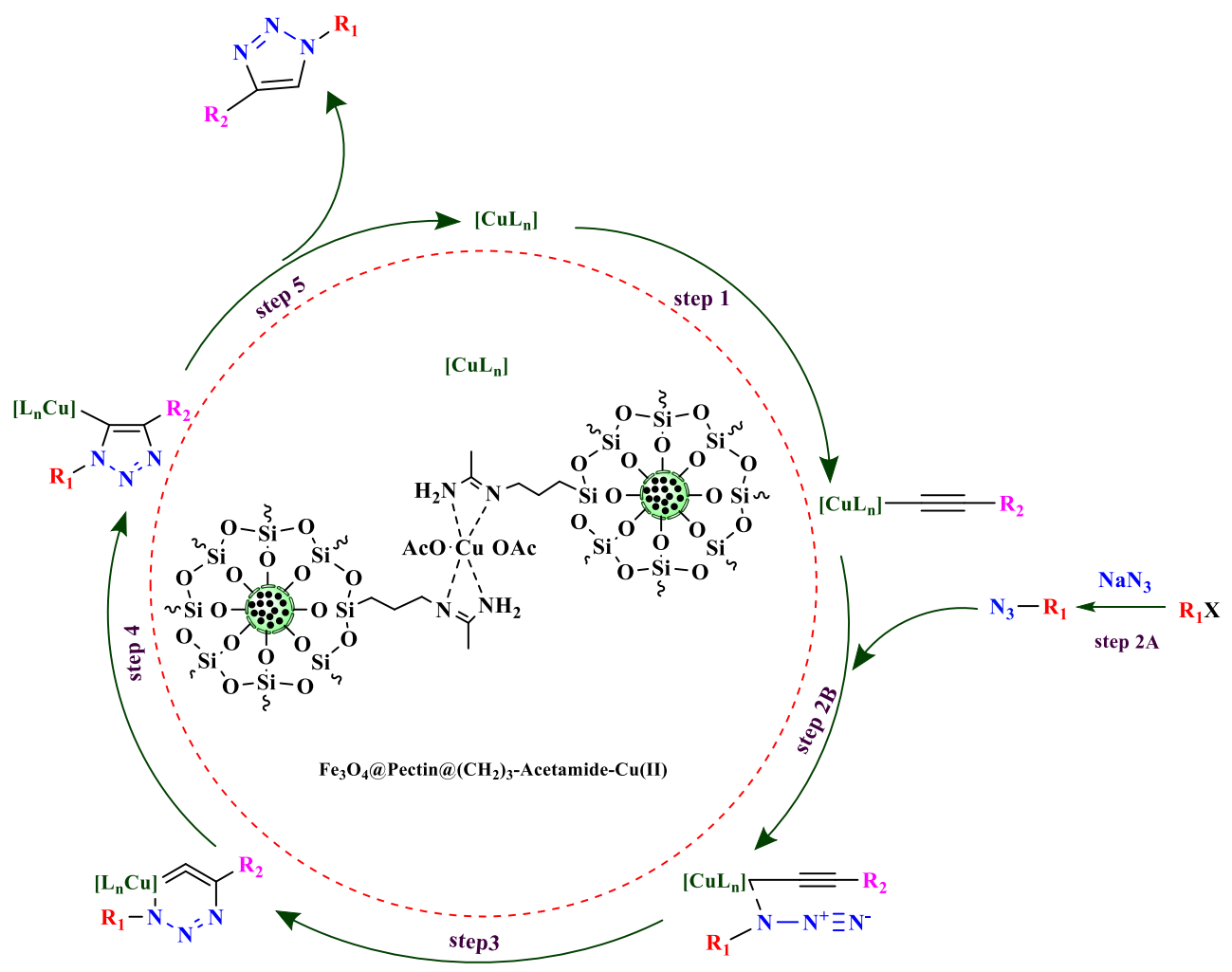

Scheme 3: Plausible mechanism for synthesis of 1,2,3- triazole derivatives by $\mathrm{Fe}_{3} \mathrm{O}_{4} @$ Pectin@ @ $\left(\mathrm{CH}_{2}\right)_{3}-\mathrm{Acetamide}-\mathrm{Cu}(\mathrm{II}) \mathrm{NPs}$ catalyst

The recyclability of the catalyst was performed for 5 cycles in optimal conditions (Fig. 9). The results indicated that the used material was also active as a catalyst for five runs without a dramatic loss of catalytic activity. These results indicate that the catalyst of $\mathrm{Fe}_{3} \mathrm{O}_{4} @$ Pectin@ $\left(\mathrm{CH}_{2}\right)_{3}$-Acetamide- $\mathrm{Cu}(\mathrm{II})$ has very good performance and stability under reaction conditions.

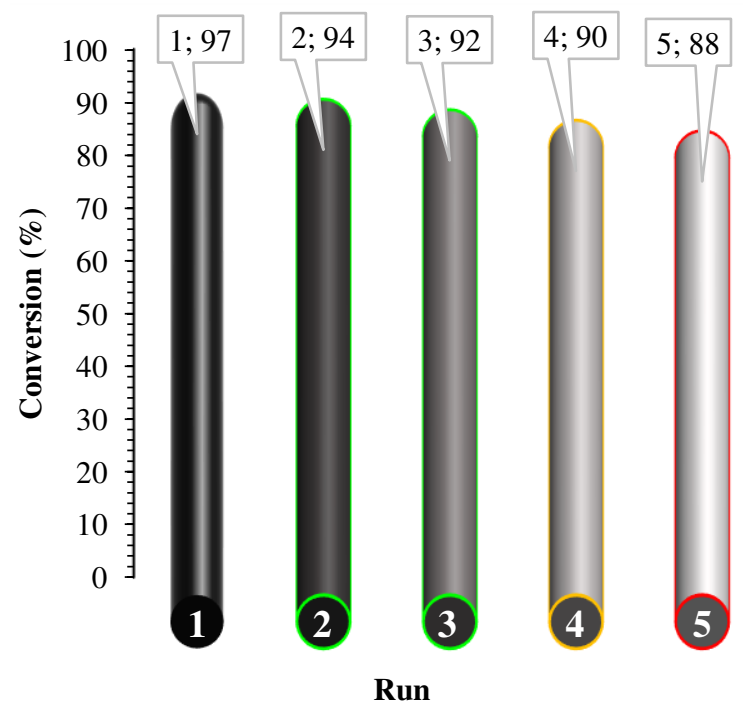

Fig. 9: Recycling potential of $\mathrm{Fe}_{3} \mathrm{O}_{4} @$ Pectin @ $\left(\mathrm{CH}_{2}\right)_{3}$-Acetamide-Cu(II) 
A special property of $\mathrm{Fe}_{3} \mathrm{O}_{4} @$ Pectin $@\left(\mathrm{CH}_{2}\right)_{3}$-Acetamide- $\mathrm{Cu}$ (II) is the stability of the framework under reaction conditions which preserves the heterogeneous nature of the system (Fig. 10). To evaluate the heterogeneous nature of $\mathrm{Fe}_{3} \mathrm{O}_{4} @$ Pectin@ $\left(\mathrm{CH}_{2}\right)_{3}$-Acetamide-Cu(II), the hot leaching test was carried out for click reaction in $\mathrm{H}_{2} \mathrm{O}$ as solvent at $65^{\circ} \mathrm{C}$. For this experiment, the catalyst was removed after 60 minutes from the reaction time, and the residual solution was stirred in the absence of $\mathrm{Fe}_{3} \mathrm{O}_{4} @$ Pectin@ $\left(\mathrm{CH}_{2}\right)_{3}$-Acetamide- $\mathrm{Cu}$ (II) for an additional 120 minutes. The result showed that no further increase in either the conversion or selectivity occurred in the absence of the catalyst. This finding established that $\mathrm{Fe}_{3} \mathrm{O}_{4} @$ Pectin @ $\left(\mathrm{CH}_{2}\right)_{3}$-Acetamide- $\mathrm{Cu}$ (II) is a typical heterogeneous catalyst.

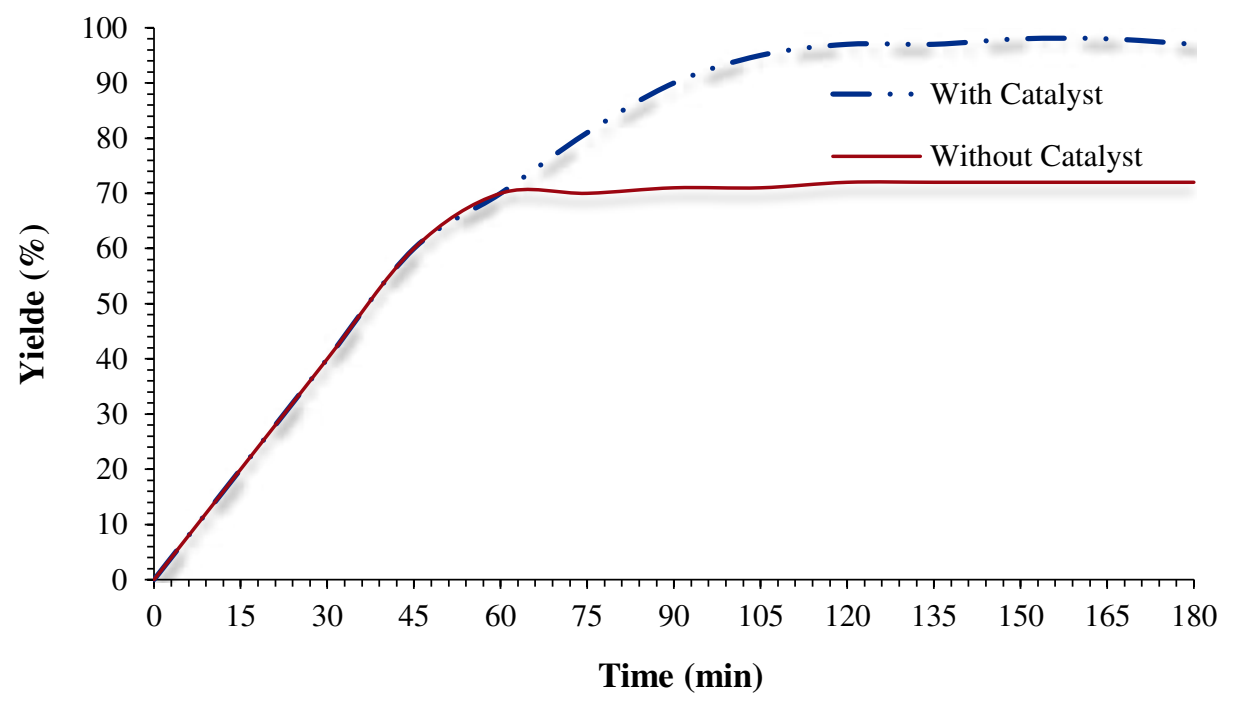

Fig. 10: Hot leaching test for click reaction using $\mathrm{Fe}_{3} \mathrm{O}_{4} @ P e c t i n @\left(\mathrm{CH}_{2}\right)_{3}$-Acetamide-Cu(II) under optimized conditions

Comparison of the catalytic activity of $\mathrm{Fe}_{3} \mathrm{O}_{4} @ P e c t i n @\left(\mathrm{CH}_{2}\right)_{3}$-Acetamide-Cu(II) catalyst in click reaction with other catalysts is shown in Table 2 for 1-benzyl-4-phenyl-1H-1,2,3-triazole and Table 3 for 1-Phenyl-2-(4-phenyl-1H-1,2,3triazole-1-yl)ethanone. So far, several catalysts that have been used, as well as to the advantages, also had disadvantages, such as including long reaction time, low efficiency, use of high temperature for preparing these compounds. In the last few years, many triazole derivatives have been considered in clinical trials. The synthesized $\mathrm{Fe}_{3} \mathrm{O}_{4} @$ Pectin@(CH2) 3 -acetamide-Cu(II) catalyst has many advantages over the reported catalysts such as suitable reaction conditions, short reaction time, high reaction efficiency, and lower catalyst amount.

\begin{tabular}{|c|c|c|c|c|c|c|c|}
\hline Entry & Catalyst & $\begin{array}{l}\text { Catalyst } \\
\text { amount }\end{array}$ & Solvent & Temp. $\left({ }^{\circ} \mathrm{C}\right)$ & Time(h) & Yield $^{\mathrm{a}}(\%)$ & Ref. \\
\hline 1 & $\mathrm{Cu} / \mathrm{C}$ & $1 \mathrm{~mol} \%$ & $\mathrm{H}_{2} \mathrm{O}$ & 100 & 1 & 91 & 77 \\
\hline 2 & POSS-SAL-Cu & $1 \mathrm{~mol} \%$ & $\mathrm{H}_{2} \mathrm{O}$ & 70 & 12 & 95 & 78 \\
\hline 3 & {$\left[\mathrm{Cu}(\mathrm{tzol})_{2}\right]$} & $1.9 \mathrm{~mol} \%$ & $\mathrm{H}_{2} \mathrm{O}$ & 70 & 12 & 96 & 79 \\
\hline 4 & CuNPs/MagSilica & $4.3 \mathrm{~mol} \%$ & $\mathrm{H}_{2} \mathrm{O}$ & 70 & 2 & 83 & 80 \\
\hline 5 & Catalysts 4 & $0.86 \mathrm{~mol} \%$ & $\mathrm{H}_{2} \mathrm{O}$ & 70 & 14 & 76 & 81 \\
\hline 6 & $\mathrm{LDH}-\mathrm{Cu}^{\mathrm{II}}$ & $0.004 \mathrm{~g}$ & $\mathrm{H}_{2} \mathrm{O}$ & 70 & 12 & 96 & 82 \\
\hline 7 & $\mathrm{HCP}-\mathrm{NHC}-\mathrm{Cu}$ & $0.45 \mathrm{~mol} \%$ & EtOH & 80 & 8 & 91 & 83 \\
\hline 8 & $\begin{array}{c}\mathrm{Fe}_{3} \mathrm{O}_{4} @ \text { Pectin @ }\left(\mathrm{CH}_{2}\right)_{3} \\
\text {-Acetamide-Cu(II) }\end{array}$ & $0.5 \mathrm{~mol} \%$ & $\mathrm{H}_{2} \mathrm{O}$ & 65 & 2 & 97 & This work \\
\hline
\end{tabular}




\begin{tabular}{|c|c|c|c|c|c|c|c|}
\hline Entry & Catalyst & $\begin{array}{l}\text { Catalyst } \\
\text { amount }\end{array}$ & Solvent & Temp. $\left({ }^{\circ} \mathrm{C}\right)$ & Time(h) & Yield $^{\mathrm{a}}(\%)$ & Ref. \\
\hline 1 & Cu NPs/Graphite & $5 \mathrm{~mol} \%$ & $\mathrm{H}_{2} \mathrm{O} / \mathrm{CH}_{3} \mathrm{OH}$ & 70 & 12 & 74 & 84 \\
\hline 2 & $\mathrm{CuFe}_{2} \mathrm{O}_{4}$ & $0.012 \mathrm{~g}$ & $\mathrm{H}_{2} \mathrm{O}$ & 70 & 8 & 78 & 85 \\
\hline 3 & $\mathrm{PAN}_{\mathrm{S} 2} \mathrm{FCu}$ & $2 \mathrm{~mol} \%$ & $\mathrm{H}_{2} \mathrm{O}$ & 60 & 3 & 91 & 86 \\
\hline 4 & $\mathrm{CuO}-\mathrm{CeO}_{2}$ & $0.1 \mathrm{~g}$ & $\mathrm{EtOH}$ & reflux & 1 & 92 & 87 \\
\hline 5 & $\mathrm{~A}-21 \mathrm{CuI}$ & $0.06: 1 \mathrm{~g}$ & acetonitrile & reflux & 1 & 89 & 88 \\
\hline 6 & Cu(II)phen@SBA-15 & $0.5 \mathrm{~mol} \%$ & $\mathrm{H}_{2} \mathrm{O}$ & 70 & $6-14$ & 87 & 89 \\
\hline 7 & CuI-USY & $0.02 \mathrm{~g}$ & $\mathrm{H}_{2} \mathrm{O}$ & 90 & 15 & 62 & 90 \\
\hline 8 & $\begin{array}{c}\mathrm{Fe}_{3} \mathrm{O}_{4} @ \text { Pectin@ }\left(\mathrm{CH}_{2}\right)_{3-} \\
\text { Acetamide-Cu(II) }\end{array}$ & $0.5 \mathrm{~mol} \%$ & $\mathrm{H}_{2} \mathrm{O}$ & 65 & 1.5 & 98 & This work \\
\hline
\end{tabular}

Finally, a series of green metrics such as atom economy (AE), atom efficiency (AEF), carbon efficiency (CE), reaction mass efficiency (RME), optimum efficiency (OE), process mass intensity (PMI), E-factor (E), solvent intensity (SI), and water intensity (WI) were calculated to evaluate the greenness of the one-pot multi-component reaction of benzyl chloride, sodium azide, phenylacetylene for 1-benzyl-4-phenyl-1H-1,2,3-triazole (Fig. 11) and Phenacyl bromide, sodium azide, phenyl acetylene for 1-Phenyl-2-(4-phenyl-1H-1,2,3-triazol-1-yl)ethanone (Fig. 12). To stable, the more greenness of the current catalyst over the reported catalysts in the one-pot multi-component reaction of benzyl chloride, sodium azide, phenylacetylene for 1-benzyl-4-phenyl-1H-1,2,3-triazole (Table 2, entries 1,3 and 9) and and Phenacyl bromide, sodium azide, phenylacetylene for 1-Phenyl-2-(4-phenyl-1H-1,2,3-triazol-1-yl)ethanone (Table 3, entries 1, 4 and 6), the current catalyst's green metrics was compared with those of three previously reported catalysts. As it is shown in Figures 11 and 12, the high values of the AE, AEF, CE, RME, and OE for the synthesis of 1-benzyl4-phenyl-1H-1,2,3-triazole and 1-Phenyl-2-(4-phenyl-1H-1,2,3-triazol-1-yl)ethanone, illustrate well the greenness of the process. The lower the PMI, E, and SI, the more favorable process is because of green chemistry.

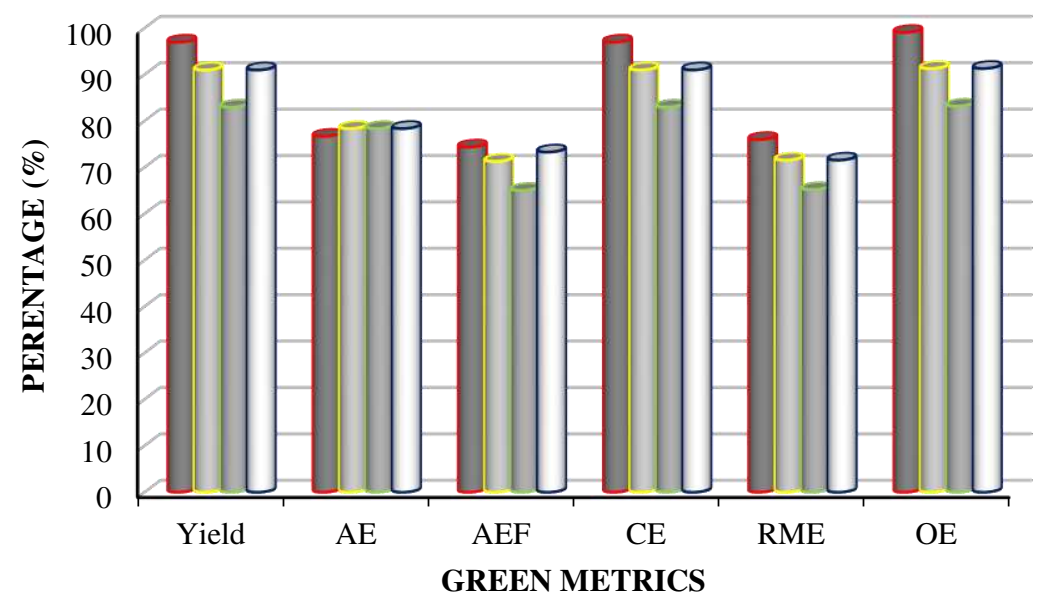

$\square$ Reaction by Fe3O4@Pectin@(CH2)3-Acetamide-Cu(II)

Reaction by $\mathrm{Cu} / \mathrm{C}$

- Reaction by CuNPs/MagSilica

$\square$ Reaction by HCP-NHC-Cu 


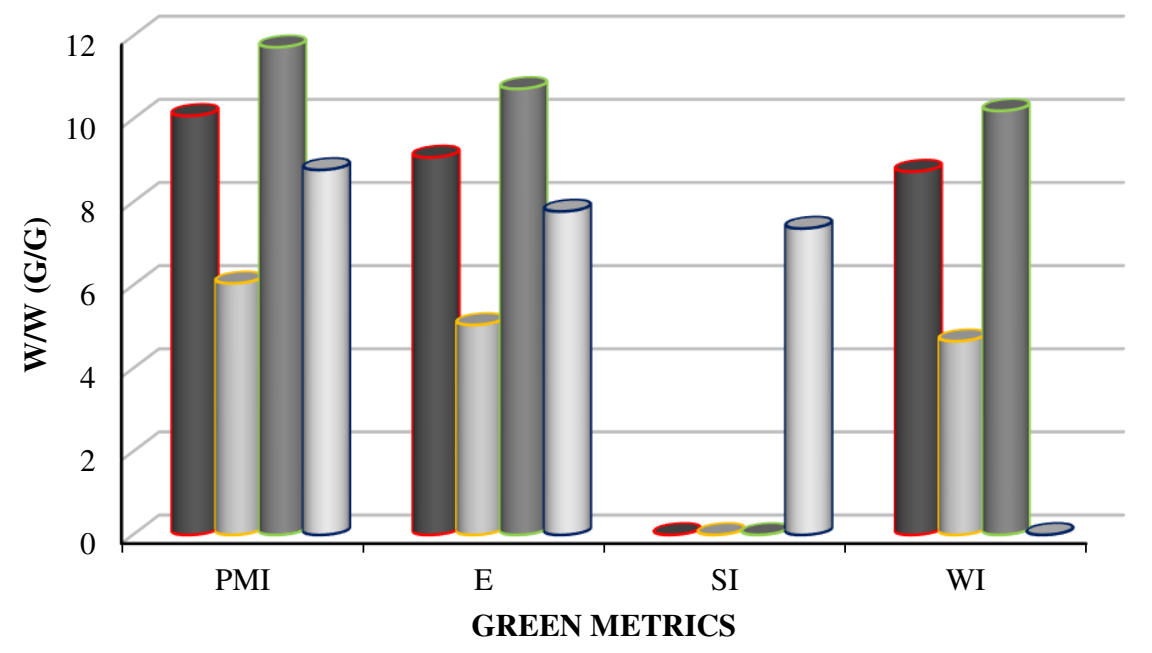

-Reaction by Fe3O4@Pectin@(CH2)3-Acetamide-Cu(II)

Reaction by $\mathrm{Cu} / \mathrm{C}$

Reaction by CuNPs/MagSilica

$\square$ Reaction by HCP-NHC-Cu

Fig. 11: Green metrics including (a) AE, AEf, CE, RME, OE and (b) PMI, E, SI and WI for the one-pot Multi-component reaction of benzyl chloride, sodium azide, phenylacetylene, and catalysed by $\mathrm{Fe}_{3} \mathrm{O}_{4} @ \mathrm{Pectin} @\left(\mathrm{CH}_{2}\right)_{3}-\mathrm{Acetamide}-\mathrm{Cu}$ (II) (this study), $\mathrm{Cu} / \mathrm{C}$ (Table 2, entry 1), CuNPs/MagSilica (Table 2, entry 4) and HCP-NHC-Cu (Table 2, entry 7); W/W = Weight/Weight $(\mathrm{g} / \mathrm{g})$

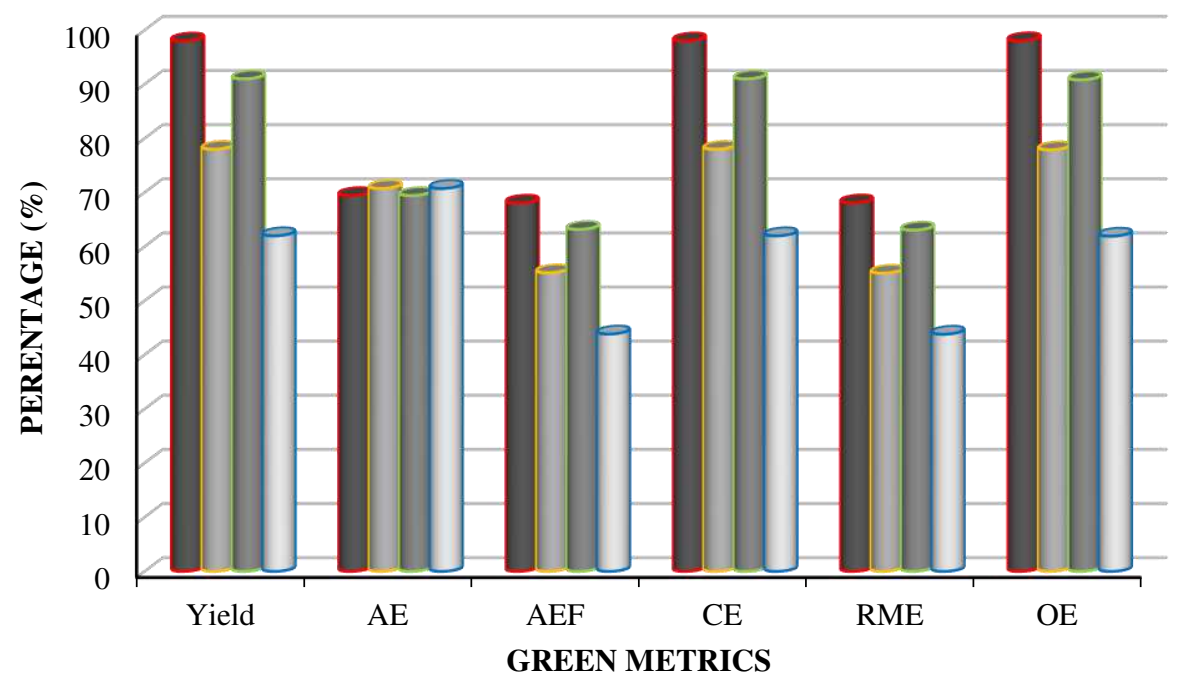

- Reaction by Fe3O4@Pectin@(CH2)3-Acetamide-Cu(II)

- Reaction by $\mathrm{CuFe} 2 \mathrm{O} 4$

Reaction by PANS2FCu

$\square$ Reaction by CuI-USY 


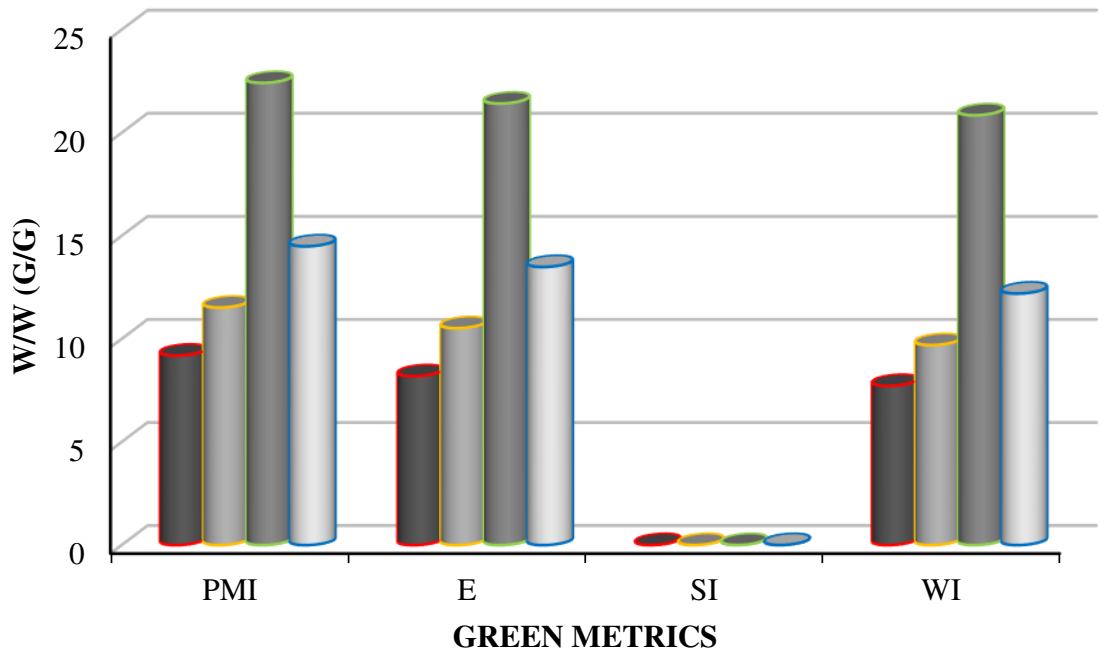

$\square$ Reaction by Fe3O4@Pectin@(CH2)3-Acetamide-Cu(II)
$\square$ Reaction by CuFe2O4
$\square$ Reaction by PANS2FCu
$\square$ Reaction by CuI-USY

Fig. 12: Green metrics including (a) AE, AEf, CE, RME, OE and (b) PMI, E, SI and WI for the one-pot Multi-component reaction of Phenacyl bromide, sodium azide, phenylacetylene, and catalysed by $\mathrm{Fe}_{3} \mathrm{O}_{4} @ \mathrm{Pectin} @\left(\mathrm{CH}_{2}\right)_{3}-\mathrm{Acetamide}-\mathrm{Cu}$ (II) (this study), $\mathrm{CuFe}_{2} \mathrm{O}_{4}$ (Table 3, entry 2), $\mathrm{PAN}_{\mathrm{s} 2} \mathrm{FCu}$ (Table 3, entry 3) and CuI-USY (Table 3, entry 7); W/W = Weight/Weight (g/g)

\section{Conclusions}

We have successfully developed a green heterogeneous catalytic system for Huisgen cycloaddition by immobilizing of copper ions on polymer-coated magnetic nanoparticles, which can be readily prepared from simple materials. The solid support was prepared from Schiff base functionalized pectin in the presence of $\mathrm{Fe}_{3} \mathrm{O}_{4}$ magnetic nanoparticles. The presence of pectin makes the prepared catalyst more cost-effective and eco-friendlier. The prepared catalyst exhibits are used for the synthesis of 1,2,3-triazole derivatives. Under the optimized reaction conditions, a wide range of 1,2,3 triazole derivatives was synthesized from various alkyl halides and alkyne using the prepared catalyst in the presence of water as a standard green solvent. This catalyst can be considered as a heterogeneous version of $\mathrm{Cu}$ (II) and can be easily prepared from starting materials. Catalyst properties include: high activity, high stability, easy recovery and reusability of the catalyst. Also, the magnetic nature of the catalyst eliminates of the need for centrifugation and filtration of the catalyst from the reaction mixture, making it possible to remove the catalyst from the reaction medium with the help of an external magnet. Finally, it can be said that the catalyst is recyclable and has good stability for click reaction.

\section{References}

1) Agalave, Sandip G., Suleman R. Maujan, and Vandana S. Pore. "FOCUS REVIEWS." Chem. Asian J 6 (2011): 2696-2718

2) Bakherad, Mohammad, et al. "Silica-anchored Cu (I) aminothiophenol complex: An efficient heterogeneous catalyst for synthesis of 1, 4-disubstituted 1, 2, 3-triazoles in water." Iranian Journal of Catalysis 8.3 (2018): 179-187.

3) Zheng, Junbao, et al. "Polyaniline-TiO2 nano-composite-based trimethylamine QCM sensor and its thermal behavior studies." Sensors and Actuators B: Chemical 133.2 (2008): 374-380 
4) Chung, C-M., et al. "Organic-inorganic polymer hybrids based on unsaturated polyester." Journal of noncrystalline solids 311.2 (2002): 195-198.

5) Ostapenko, N., et al. "Conformation change of nanosized silicon-organic polymer oriented into ordered nanoporous silicas." Thin Solid Films 516.24 (2008): 8944-8948.

6) Mark, James E. "Some novel polymeric nanocomposites." Accounts of chemical research 39.12 (2006): 881888.

7) Run, M. T., et al. "A polymer/mesoporous molecular sieve composite: Preparation, structure and properties." Materials Chemistry and Physics 105.2-3 (2007): 341-347.

8) Huisgen, Rolf, Günter Szeimies, and Leander Möbius. "1.3-Dipolare Cycloadditionen, XXXII. Kinetik der Additionen organischer Azide an CC-Mehrfachbindungen." Chemische Berichte 100.8 (1967): 2494-2507.

9) V. V. Rostovtsev, L. G. Green, V. V. Folkin and K. B. Sharpless, Angew. Chem., Int. Ed., 2002, 41, 25962599.

10) Tornøe, Christian W., Caspar Christensen, and Morten Meldal. "Peptidotriazoles on solid phase:[1, 2, 3]triazoles by regiospecific copper (I)-catalyzed 1,3-dipolar cycloadditions of terminal alkynes to azides." The Journal of organic chemistry 67.9 (2002): 3057-3064.

11) a) Selected reviews: C. J. Pickens, S. N. Johnson, M. M. Pressnall, M. A. Leon and C. J. Berkland, Bioconjugate Chem., 2018, 29, 686-701. b) A. D. Pehere, X. Zhang and A. D. Abell, Aust. J. Chem., 2017, 70, 138-151. c) V. K. Tiwari, B. B. Mishra, K. B. Mishra, N. Mishra, A. S. Singh and X. Chen, Chem. Rev., 2016, 116, 3086- 3240. d) C. Wang, D. Ikhlef, S. Kahlal, J.-Y. Saillard and D. Astruc, Coord. Chem. Rev., 2016, 316, 1. e) X. Wang, B. Huang, X. Liu and P. Zhan, Drug Discovery Today, 2016, 21, 118; M. S. Singh, S. Chowdhury and S. Koley, Tetrahedron, 2016, 72, 5257-5283. f) M. Arseneault, C. Wafer and J. F. Morin, Molecules, 2015, 20, 9263-9294. g) P. Thirumurugan, D. Matosiuk and K. Jozwiak, Chem. Rev., 2013, 113, 4905-4979. h) M. V. Walter and M. Malkoch, Chem. Soc. Rev., 2012, 41, 4593; L. Liang and D. Astruc, Coord. Chem. Rev., 2011, 255, 2933. i) G. Franc and A. K. Kakkar, Chem. Soc. Rev., 2010, 39, 1536. g) K. D. Hanni and D. A. Leigh, Chem. Soc. Rev., 2010, 39, 1240. h) A. H. ElSagheer and T. Brown, Chem. Soc. Rev., 2010, 39, 1388-1405. i) J. M. Holub and K. Kirshenbaum, Chem. Soc. Rev., 2010, 39, 1325-1337.

12) Meldal, Morten, and Frederik Diness. "Recent fascinating aspects of the CuAAC click reaction." Trends in Chemistry (2020).

13) Ju, Changhong, et al. "Construction of sequence-defined polytriazoles by IrAAC and CuAAC reactions." Chemical Communications 56.28 (2020): 3955-3958.

14) Zeng, Fang, Mingjuan Zhang, and Yiqun Li. "Cu2+ ion crosslinked carboxymethylcellulose/diatomite composite beads as an efficient catalyst for CuAAC reactions." Polymers for Advanced Technologies (2021).

15) Martínez-Haya, Rebeca, et al. "Mechanistic Insight into the Light-Triggered CuAAC Reaction: Does Any of the Photocatalyst Go?." The Journal of Organic Chemistry 86.8 (2021): 5832-5844.

16) $\mathrm{Wu}$, Jianrong, et al. "Synthesis and properties of anion conductive polymers containing dual quaternary ammonium groups without beta-hydrogen via CuAAC click chemistry." Polymer (2021): 123920

17) Yang, Cangjie, James P. Flynn, and Jia Niu. "Facile Synthesis of Sequence-Regulated Synthetic Polymers Using Orthogonal SuFEx and CuAAC Click Reactions." Angewandte Chemie International Edition 57.49 (2018): 16194-16199.

18) $\mathrm{Fu}$, Fangyu, et al. "Exposure to air boosts CuAAC reactions catalyzed by PEG-stabilized Cu nanoparticles." Chemical Communications 53.39 (2017): 5384-5387. 
19) Karan, Chandan Kumar, Mohan Chandra Sau, and Manish Bhattacharjee. "A copper (ii) metal-organic hydrogel as a multifunctional precatalyst for $\mathrm{CuAAC}$ reactions and chemical fixation of $\mathrm{CO} 2$ under solvent free conditions." Chemical Communications 53.9 (2017): 1526-1529.

20) Huang, Yu, et al. "Synthesis of graphene quantum dots stabilized CuNPs and their applications in CuAAC reaction and 4-nitrophenol reduction." Inorganic Chemistry Communications 110 (2019): 107588.

21) Mandal, Bablu Hira, et al. "Bio-waste corn-cob cellulose supported poly (hydroxamic acid) copper complex for Huisgen reaction: waste to wealth approach." Carbohydrate polymers 156 (2017): 175-181.

22) Tran, Thi V., Garret Couture, and Loi H. Do. "Evaluation of dicopper azacryptand complexes in aqueous CuAAC reactions and their tolerance toward biological thiols." Dalton Transactions 48.26 (2019): 9751-9758.

23) Nasrollahzadeh, Mahmoud, and S. Mohammad Sajadi. "Green synthesis of copper nanoparticles using Ginkgo biloba L. leaf extract and their catalytic activity for the Huisgen [3+2] cycloaddition of azides and alkynes at room temperature." Journal of colloid and interface science 457 (2015): 141-147.

24) Lai, Bingbing, et al. "Silica-supported metal acetylacetonate catalysts with a robust and flexible linker constructed by using 2-butoxy-3, 4-dihydropyrans as dual anchoring reagents and ligand donors." Catalysis Science \& Technology 6.6 (2016): 1810-1820.

25) Kiani, Mahsa, et al. "Synthesis, Characterisation and Crystal structure of a New Cu (II)-carboxamide Complex and $\mathrm{CuO}$ nanoparticles as New Catalysts in the $\mathrm{CuAAC}$ reaction and Investigation of their Antibacterial activity." Inorganica Chimica Acta 506 (2020): 119514.

26) Bi, Fangchao, et al. "Substitution of terminal amide with 1H-1, 2, 3-triazole: Identification of unexpected class of potent antibacterial agents." Bioorganic \& medicinal chemistry letters 28.5 (2018): 884-891.

27) Sepehri, Nima, et al. "Synthesis, characterization, molecular docking, and biological activities of coumarin-1, 2, 3-triazole-acetamide hybrid derivatives." Archiv der Pharmazie 353.10 (2020): 2000109.

28) Gholinejad, Mohammad, and Neda Jeddi. "Copper nanoparticles supported on agarose as a bioorganic and degradable polymer for multicomponent click synthesis of 1,2,3-triazoles under low copper loading in water." ACS Sustainable Chemistry \& Engineering 2.12 (2014): 2658-2665.

29) Zhu, Xiaohang, et al. "Preparation of recoverable Fe 304 @ PANI-Pd II core/shell catalysts for Suzuki carbonylative cross-coupling reactions." New Journal of Chemistry 38.9 (2014): 4622-4627.

30) Kumar, BSP Anil, et al. "Copper on chitosan: an efficient and easily recoverable heterogeneous catalyst for one pot synthesis of 1,2,3-triazoles from aryl boronic acids in water at room temperature." Tetrahedron Letters 56.15 (2015): 1968-1972.

31) Lai, Bingbing, et al. "Silica-supported metal acetylacetonate catalysts with a robust and flexible linker constructed by using 2-butoxy-3, 4-dihydropyrans as dual anchoring reagents and ligand donors." Catalysis Science \& Technology 6.6 (2016): 1810-1820.

32) Bagherzade, Ghodsieh, and Hossein Eshghi. "Design and synthesis of magnetic $\mathrm{Fe}_{3} \mathrm{O}_{4} @ \mathrm{NFC}-\mathrm{ImSalophCu}$ nanocatalyst based on cellulose nanofibers as a new and highly efficient, reusable, stable and green catalyst for the synthesis of 1, 2, 3-triazoles." RSC Advances 10.54 (2020): 32927-32937.

33) Bakherad, Mohammad, Raheleh Doosti, and Zeynab Qasemifar. "Synthesis of 1, 4-disubstituted 1, 2, 3-triazoles Catalyzed by Eggshell-supported-Cu (I) Metformin Complex as a Heterogeneous Catalyst in Water." Journal of Applied Chemical Research 14.1 (2020): 8-20.

34) Nia, Ali Shaygan, et al. "Click chemistry promoted by graphene supported copper nanomaterials." Chemical Communications 50.97 (2014): 15374-15377. 
35) Wang, D., Zhao, M., Liu, X., Chen, Y., Li, N., and Chen, B. IQuick and highly e cient copper-catalyzed cycloaddition of organic azides with terminal alkynes", Org. Biomol. Chem., 10(2), pp. 229-231 (2012).

36) Ji, P., Atherton, J.H., and Page, M.I. ICopper catalysed azide-alkyne cycloaddition (CuAAC) in liquid ammonia", Org. Biomol. Chem., 10(39), pp. 7965-7969 (2012).

37) Gonda, Z. and Novak, Z. \Highly active coppercatalysts for azide-alkyne cycloaddition", Dalton Trans., 39(3), pp. 726-729 (2010).

38) Bai, S.Q., Jiang, L., Zuo, J.L., and Hor, T.S.A. \Hybrid NS ligands supported Cu(i)/(ii) complexes for azidealkyne cycloaddition reactions", Dalton Trans., 42(31), pp. 11319-11326 (2013).

39) Q. HU, W. Jia, F. CHEN, J. SHEN, Chem. Res. Chinese Univ. 2006, 22, 792-796.

40) a) A.-H. Lu; W. Schmidt; N. Matoussevitch; H. Bönnemann; B. Spliethoff; B. Tesche; E. Bill; W. Kiefer; F. Schüth (August 2004). "Nanoengineering of a Magnetically Separable Hydrogenation Catalyst". Angewandte Chemie International Edition. 43 (33): 4303-4306. doi:10.1002/anie.200454222. PMID 15368378.

41) A. K. Gupta; M. Gupta (June 2005). "Synthesis and surface engineering of iron oxide nanoparticles for biomedical applications". Biomaterials. 26 (18): 3995-4021. doi:10.1016/j.biomaterials.2004.10.012. PMID 15626447.

42) Ramaswamy, B; Kulkarni, SD; Villar, PS; Smith, RS; Eberly, C; Araneda, RC; Depireux, DA; Shapiro, B (24 June 2015). "Movement of magnetic nanoparticles in brain tissue: mechanisms and safety". Nanomedicine: Nanotechnology, Biology and Medicine. 11 (7): 1821-9. doi:10.1016/j.nano.2015.06.003. PMC 4586396. PMID 26115639.

43) He, Le; Wang, Mingsheng; Ge, Jianping; Yin, Yadong (18 September 2012). "Magnetic Assembly Route to Colloidal Responsive Photonic Nanostructures". Accounts of Chemical Research. 45 (9): 1431-1440. doi:10.1021/ar200276t. PMID 22578015.

44) Kavre, Ivna; Kostevc, Gregor; Kralj, Slavko; Vilfan, Andrej; Babič, Dušan (13 August 2014). "Fabrication of magneto-responsive microgears based on magnetic nanoparticle embedded PDMS". RSC Advances. 4 (72): 38316-38322. doi:10.1039/C4RA05602G.

45) Mornet, S.; Vasseur, S.; Grasset, F.; Veverka, P.; Goglio, G.; Demourgues, A.; Portier, J.; Pollert, E.; Duguet, E. (July 2006). "Magnetic nanoparticle design for medical applications". Progress in Solid State Chemistry. 34 (2-4): 237-247. doi:10.1016/j.progsolidstchem.2005.11.010.

46) B. Gleich; J. Weizenecker (2005). "Tomographic imaging using the nonlinear response of magnetic particles". Nature. 435 (7046): 1214-1217. Bibcode:2005Natur.435.1214G. doi:10.1038/nature03808. PMID 15988521. S2CID 4393678.

47) Hyeon, Taeghwan (3 April 2003). "Chemical synthesis of magnetic nanoparticles". Chemical Communications (8): 927-934. doi:10.1039/B207789B. PMID 12744306. S2CID 27657072.

48) Natalie A. Frey and Shouheng Sun Magnetic Nanoparticle for Information Storage Applications

49) Elliott, Daniel W.; Zhang, Wei-xian (December 2001). "Field Assessment of Nanoscale Bimetallic Particles for Groundwater Treatment". Environmental Science \& Technology. 35 (24): 4922-4926.

Bibcode:2001EnST...35.4922E. doi:10.1021/es0108584. PMID 11775172.

50) J. Philip; Shima.P.D. B. Raj (2006). "Nanofluid with tunable thermal properties". Applied Physics Letters. 92 (4): 043108. Bibcode:2008ApPhL..92d3108P. doi:10.1063/1.2838304. 
51) Chaudhary, V.; Wang, Z.; Ray, A.; Sridhar, I.; Ramanujan, R. V. (2017). "Self pumping magnetic cooling". Journal of Physics D: Applied Physics. 50 (3): 03LT03. Bibcode:2017JPhD...50cLT03C. doi:10.1088/1361 6463/aa4f92.

52) J.Philip; T.J.Kumar; P.Kalyanasundaram; B.Raj (2003). "Tunable Optical Filter". Measurement Science and Technology. 14 (8): 1289-1294. Bibcode:2003MeScT..14.1289P. doi:10.1088/0957-0233/14/8/314.

53) Mahendran, V. (2012). "Nanofluid based opticalsensor for rapid visual inspection of defects in ferromagnetic materials". Appl. Phys. Lett. 100 (7): 073104. Bibcode:2012ApPhL.100g3104M. doi:10.1063/1.3684969.

54) Chaudhary, V.; Ramanujan, R. V. (11 October 2016). "Magnetocaloric Properties of Fe-Ni-Cr Nanoparticles for Active Cooling". Scientific Reports. 6 (1): 35156. Bibcode:2016NatSR...635156C. doi:10.1038/srep35156. PMC 5057077. PMID 27725754.

55) Chaudhary, V.; Chen, X.; Ramanujan, R.V. (February 2019). "Iron and manganese based magnetocaloric materials for near room temperature thermal management". Progress in Materials Science. 100: 64-98. doi:10.1016/j.pmatsci.2018.09.005.

56) Philip, V. Mahendran; Felicia, Leona J. (2013). "A Simple, In-Expensive and Ultrasensitive Magnetic Nanofluid Based Sensor for Detection of Cations, Ethanol and Ammonia". Journal of Nanofluids. 2 (2): 112 119. doi:10.1166/jon.2013.1050.

57) R. Hudson, Y. Feng, R. S. Varma and A. Moores, Green Chem., 2014, 16, 4493-4505.

58) X. Zhu, J. Niu, F. Zhang, J. Zhou, X. Li and J. Ma, New J. Chem., 2014, 38, 4622-4627.

59) T. A. Salah El-Din, A. A. Elzatahry, D. M. Aldhayan, A. M. AlEnizi and S. S. Al-Deyab, Int. J. Electrochem. Sci., 2011, 6, 6177-6183.

60) S. Xuan, W. Jiang, X. Gong, Y. Hu and Z. Chen, J. Phys. Chem. C, 2009, 113, 553-558.

61) S. P. Pujari, L. Scheres, A. T. M. Marcelis and H. Zuilhof, Angew. Chem., Int. Ed., 2014, 53, 6322-6356.

62) Z. Chen, Z. Xue, L. Chen, Z. Geng, R. Yang, L. Chena and Z. Wang, New J. Chem., 2013, 37, 3731-3736.

63) T. Baran, J. Colloid Interface Sci. 2017, 496, 446-455.

64) S. E. S. Leonhardt, A. Stolle, B. Ondruschka, G. Cravotto, C. De Leo, K. D. Jandt, T. F. Keller, Appl. Catal. A Gen. 2010, 379, 30-37.

65) Wang, Hongjuan, et al. "Effects of ripening stage and cultivar on physicochemical properties and pectin nanostructures of jujubes." Carbohydrate Polymers 89.4 (2012): 1180-1188.

66) T. Biswal, B. Barik and P. K. Sahoo, J Mater Sci Nanotechnol. 2016, 4, 203.

67) H. Khashei Siuki, G. Bagherzade and P. Ghamari Kargar, ChemistrySelect, 2020, 5, 13537-13544.

68) S. Chidambaram, B. Pari, N. Kasi and S. Muthusamy, J. Alloys Compd., 2016, 665, 404-410.

69) H. Esmaeili-Shahri, H. Eshghi, J. Lari and S. A. Rounaghi, Appl. Organomet. Chem., 2018, 32, e3947.

70) Z. A. Hajar Khanehzaei, Mansor B Ahmad*, Kamyar Shameli*, Int. J. Electrochem. Sci., 2014, 9, 8189-8198.

71) Ebrahimpour-Malamir, F., Hosseinnejad, T., Mirsafaei, R., \& Heravi, M. M. (2018). Synthesis, characterization and computational study of $\mathrm{CuI}$ nanoparticles immobilized on modified poly (styrene-comaleic anhydride) as a green, efficient and recyclable heterogeneous catalyst in the synthesis of 1,4disubstituted 1, 2, 3-triazoles via click reaction. Applied Organometallic Chemistry, 32(1), e3913. 
72) Nemati, F., Heravi, M. M., \& Elhampour, A. (2015). Magnetic nano-Fe 3 O 4 @ TiO 2/Cu 2 O core-shell composite: an efficient novel catalyst for the regioselective synthesis of 1,2,3-triazoles using a click reaction. RSC Advances, 5(57), 45775-45784.

73) Baie Lashaki, T., Oskooie, H. A., Hosseinnejad, T., \& Heravi, M. M. (2017). CuI nanoparticles on modified poly (styrene-co-maleic anhydride) as an effective catalyst in regioselective synthesis of 1,2,3-triazoles via click reaction: a joint experimental and computational study. Journal of Coordination Chemistry, 70(11), 18151834 .

74) Bagherzade, G., \& Eshghi, H. (2020). Design and synthesis of magnetic $\mathrm{Fe}_{3} \mathrm{O}_{4} @$ NFC-ImSalophCu nanocatalyst based on cellulose nanofibers as a new and highly efficient, reusable, stable and green catalyst for the synthesis of 1, 2, 3-triazoles. RSC Advances, 10(54), 32927-32937.

75) E. Hashemi, Y. S. Beheshtiha, S. Ahmadi and M. M. Heravi, Transition Met. Chem., 2014, 5, 593-601.

76) B. A. Dar, A. Bhowmik, A. Sharma, P. R. Sharma, A. Lazar, A. Singh, M. Sharma, B. Singh, Appl. Clay Sci. 2013, 80, 351-357.

77) H. Sharghi, R. Khalifeh, M. M. Doroodmand, Adv. Synth. Catal. 2009, 351, 207-218

78) Akbari, Ali, et al. "Cube-octameric silsesquioxane-mediated cargo copper Schiff base for efficient click reaction in aqueous media." Journal of Molecular Catalysis A: Chemical 414 (2016): 47-54.

79) M. Amini, A. Bayrami, M.N. Marashi, A. Arab, A. Ellern, L.K. Woo, Inorg. Chim. Acta 443 (2016) 22-27;

80) F. Nador, M.A. Volpe, F. Alonso, A. Feldhoff, A. Kirschning, G. Radivoy, Appl. Catal., A 455 (2013) 39-45.

81) Bagherzadeh, Mojtaba, et al. "Synthesis, characterization, and comparison of two new copper (II) complexes containing Schiff-base and diazo ligands as new catalysts in CuAAC reaction." Inorganica Chimica Acta 492 (2019): 213-220

82) Amini, M., Nikkhoo, M., \& F. Farnia, S. M. (2017). Synthesis, characterization and catalytic properties of tetrachlorocuprate (II) immobilized on layered double hydroxide. Applied Organometallic Chemistry, 31(9), e3710.

83) Jia, Z., Wang, K., Li, T., Tan, B., \& Gu, Y. (2016). Functionalized hypercrosslinked polymers with knitted Nheterocyclic carbene-copper complexes as efficient and recyclable catalysts for organic transformations. Catalysis Science \& Technology, 6(12), 4345-4355.

84) d'Halluin, M., Mabit, T., Fairley, N., Fernandez, V., Gawande, M. B., Le Grognec, E., \& Felpin, F. X. (2015). Graphite-supported ultra-small copper nanoparticles-Preparation, characterization and catalysis applications. Carbon, 93, 974-983.

85) Kumar, B. A., Reddy, K. H. V., Madhav, B., Ramesh, K., \& Nageswar, Y. V. D. (2012). Magnetically separable $\mathrm{CuFe}_{2} \mathrm{O}_{4}$ nano particles catalyzed multicomponent synthesis of 1, 4-disubstituted 1, 2, 3-triazoles in tap water using 'click chemistry'. Tetrahedron Letters, 53(34), 4595-4599.

86) Li, P., Liu, Y., Wang, L., Xiao, J., \& Tao, M. (2018). Copper (II)-Schiff Base Complex-Functionalized Polyacrylonitrile Fiber as a Green Efficient Heterogeneous Catalyst for One-Pot Multicomponent Syntheses of 1, 2, 3-Triazoles and Propargylamines. Advanced Synthesis \& Catalysis, 360(8), 1673-1684.

87) Albadi, J., Shiran, J. A., \& Mansournezhad, A. (2014). Click synthesis of 1, 4-disubstituted-1, 2, 3-triazoles catalysed by $\mathrm{CuO}-\mathrm{CeO} 2$ nanocomposite in the presence of amberlite-supported azide. Journal of Chemical Sciences, 126(1), 147-150.

88) Albadi, J., \& Keshavarz, M. (2013). Polymer-Supported Azide and Copper (I): Green Reusable Reagent and Catalyst for Click Cyclization. Synthetic Communications, 43(15), 2019-2030.

89) Nunes, A., Djakovitch, L., Khrouz, L., Felpin, F. X., \& Dufaud, V. (2017). Copper (II)-phenanthroline hybrid material as efficient catalyst for the multicomponent synthesis of 1,2,3-triazoles via sequential azide formation/1, 3-dipolar cycloaddition. Molecular Catalysis, 437, 150-157. 
90) Bénéteau, V., Olmos, A., Boningari, T., Sommer, J., \& Pale, P. (2010). Zeo-click synthesis: CuI-zeolitecatalyzed one-pot two-step synthesis of triazoles from halides and related compounds. Tetrahedron Letters, 51(28), 3673-3677. 


\section{Supplementary Files}

This is a list of supplementary files associated with this preprint. Click to download.

- Supportinglnformation.pdf 